\title{
ICONOCLASIA ANTIBORBÓNICA EN ESPAÑA: EL REPUDIO SIMBÓLICO DE ISABEL II DURANTE LA REVOLUCIÓN DE $1868^{1}$
}

\section{ANTIBORBONIC ICONOCLASM IN SPAIN: THE SYMBOLIC REPUDIATION OF ISABEL II DURING THE REVOLUTION OF 1868}

\author{
Sergio Sánchez Collantes \\ Universidad de Burgos
}

\begin{abstract}
SUMARIO: I. LA DESTRUCCIÓN DE RETRATOS Y BUSTOS: MÁS QUE UN DESTRONAMIENTO SIMBÓLICO.- II. LA ESCENIFICACIÓN LOCAL DEL FINAL DE UN RÉGIMEN.- III. OTRAS EXPRESIONES DEL REPUDIO.- IV. BALANCE: LA MULTIFUNCIONAL ICONOCLASIA ANTIBORBÓNICA DE 1868.
\end{abstract}

Resumen: Cuando estalló la revolución de 1868, Isabel II era una soberana repudiada. En la primera fase del movimiento que provocó su exilio, hubo una serie de brotes de iconoclasia política en los cuales la multitud se ensañó con las imágenes de la reina, ya fueran retratos o bustos, y en general con todos los símbolos o emblemas de la dinastía borbónica. En este artículo se repasan y describen dichos episodios con el fin de analizar sus múltiples significados y funciones.

\begin{abstract}
When the revolution of 1868 broke out, Isabel II was a hated queen. In the first phase of the movement that led to his exile, there were outbreaks of political iconoclasm in which the crowd destroyed the images of the sovereign, whether portraits or busts, and in general with all the symbols or emblems of the Bourbon dynasty. In this article, these episodes are reviewed and described in order to analyze their multiple meanings and functions.
\end{abstract}

Palabras clave: Iconoclasia política, Monarquía, Revolución de 1868, Movilización popular, Simbolos políticos.

Key Words: Political iconoclasm, Monarchy, Revolution of 1868, Popular mobilization, Political symbols.

\footnotetext{
${ }^{1}$ Investigación realizada en el marco del proyecto HAR2016-75954-P, financiado por el Ministerio de Economía y Competitividad. Los resultados contenidos en este artículo fueron presentados en el congreso internacional Le monarchie dell'Europa meridionale e le sfide della modernità, celebrado en Nápoles en diciembre de 2018, por lo que también se han beneficiado de los debates alli mantenidos.
} 
"Ninguna reina ha sido en el mundo más querida que Isabel, y ninguna ha bajado del solio más despreciada".

Eugenio García Ruiz, Historias, tomo II, Est. Tip. de A. Bacaycoa, Madrid, 1878, p. 724.

\begin{abstract}
"Seis horas bastaron ayer para que desaparecieran todos los signos y emblemas que pueden recordar al pueblo de Madrid la dinastía de los Borbones.

Veinte y cuatro horas antes decian sin embargo los seides de Isabel que su dinastía se hallaba profundamente arraigada en el pueblo español".

El Imparcial, 1 de octubre de 1868.
\end{abstract}

“¡Los pueblos! ¡Vaya usted a quitarles su delirio del momento y expóngase a que le arrastren!".

Emilio Gutiérrez Gamero, Mis primeros ochenta años, I, Aguilar, Madrid, 1962, p. 235.

\title{
I. LA DESTRUCCIÓN DE RETRATOS Y BUSTOS: MÁS QUE UN DESTRONAMIENTO SIMBÓLICO
}

En todos los relatos sobre la primera fase de La Gloriosa, incluso si se circunscriben a una determinada localidad o provincia, suele repetirse un esquema en el que -dejando de lado los precedentes inmediatos- normalmente sobresalen tres elementos: primero, la batalla de Alcolea o sus remedos locales cuando existieron (con frecuencia, tentativas de partidas que más bien aguardaban el triunfo revolucionario); segundo, el bullicio en las calles, con la paralela difusión de las proclamas, los himnos y los gritos - entre otros- de “¡abajo los Borbones!” o “¡viva España con honra!”; y por último, la formación de las juntas revolucionarias, que generalmente acaparan el mayor interés historiográfico por las medidas o aspiraciones que defendian y sus variantes locales.

Lo que interesa para este trabajo es la movilización popular que se produjo desde finales de septiembre de 1868 en las calles y plazas de numerosas localidades españolas; más concretamente, la destrucción ritual de los símbolos y las imágenes del régimen isabelino. No era una revolución contra la monarquía, sino contra una dinastía o, si se quiere, contra una forma de entender la monarquía. Limitándonos a los primeros días y semanas del nuevo periodo abierto por La Gloriosa, nos centraremos en los actos dirigidos contra emblemas alusivos a los Borbones y, por extensión, a la monarquía isabelina. Ni que decir tiene que no se trataba de simple vandalismo, aunque pueda haber autores que así lo hayan considerado históricamente ${ }^{2}$.

Esta destrucción no era totalmente ignorada por la historiografia, gracias a las referencias vertidas en bastantes investigaciones locales - las mencionadas

\footnotetext{
2 Louis Réau, Histoire du vandalisme. Les monuments détruits de l'art français, 2 vols., Hachette, Paris, 1959. El uso del término vandalismo remitiria más a la iconoclasia propiamente política, como se recuerda en Peter Burke, Visto y no visto. El uso de la imagen como documento histórico, Crítica, Barcelona, 2005, p. 97.
} 
aquí y otras-, pero también por estudios como los de Gregorio de la Fuente Monge, quizás el único que consideró relevante su análisis específico como parte de la que llama "fiesta revolucionaria"3, un sintagma previamente introducido por el canónico ensayo de Mona Ozouf ${ }^{4}$. El presente artículo profundiza en el análisis de esa destrucción simbólica de forma monográfica pero englobándola conceptualmente dentro de la noción de iconoclasia, término que llamativamente ha sido utilizado en contados trabajos por la historiografia española sobre el periodo $^{5}$. En otros países, sin embargo, la iconoclasia ha suscitado interés no sólo en su tradicional modalidad religiosa, sino también en sus numerosas manifestaciones políticas ${ }^{6}$. En relación con la época contemporánea, la cuestión sigue despertando interés y hay mucho campo por trabajar, como demostró el congreso Iconoclasme et Révolutions. XVIII ${ }^{e}-X X I^{e}$ siècles, organizado en Francia en diciembre de $2012^{7}$, o la realización, en los últimos tiempos, de otras investigaciones sobre Italia ${ }^{8}$.

En sus múltiples variantes históricas, la iconoclasia política ha sido objeto de bastantes reflexiones teóricas. Vaya por delante una idea sencilla pero útil como punto de partida: todo régimen político que suplanta a otro de forma rupturista trata de eliminar la simbología precedente y, en su lugar, crear la suya propia ${ }^{9}$. En ello subyace también un problema de legitimidad y, por extensión, el deseo de expiar un recuerdo - una memoria- que se percibe como una mancha ${ }^{10}$. En el tema que nos ocupa, el furor popular hacia las imágenes de Isabel II no se comprende sin tener en cuenta lo que simbolizaban los retratos

\footnotetext{
3 Gregorio de la Fuente Monge, Los revolucionarios de 1868. Elites y poder en la España liberal, Marcial Pons, Madrid, 2000.

${ }^{4}$ Mona Ozouf, La fête révolutionnaire 1789-1799, Gallimard, Paris, 1976.

5 Desde luego que se pueden hallar excepciones y cada vez es menos raro verlo (un ejemplo reciente, en Ignacio Peiró Martín, En los altares de la patria. La construcción de la cultura nacional española, Akal, Madrid, 2017). Incluso en quienes escribieron sobre ello en el pasado: véase como muestra Apeles Mestres, Recorts y fantasies, Fidel Giró Impresor, Barcelona, 1906, p. 31: "Després de cremats els retratos reials en la plaça de Sant Jaume, van destacarse en totes direccions - com he dit- grupos d'iconoclastes, disposats a repetir l'auto de fe ab tots el demés retratos d'Isabel II, que existien en els edificis públics".

6 Sobre todo desde la década de 1950, como se recuerda en Olivier Christin, Une révolution symbolique: l'iconoclasme huguenot et la reconstruction catholique, Les Éditions de Minuit, Paris, 1991, p. 9.

7 Cuyos resultados fueron publicados en Emmanuel Fureix (dir.), Iconoclasme et révolutions. De 1789 à nos jours, Champ Vallon, Ceyzérieu, 2014. Sobre esta temática, acaba de ver la luz Emmanuel Fureix, L'oeil blessé. Politiques de l'iconoclasme après la Révolution française, Champ Vallon, Ceyzérieu, 2019.

8 Sirva de muestra el trabajo de investigación que recientemente desarrolló Christopher Calefati en la Università degli Studi di Bari Aldo Moro, bajo el título ""Gli abbiamo tagliato la testa". Repertori e attori dell'iconoclastia politica nelle Puglie del 1848-49". En el congreso Le monarchie dell'Europa meridionale e le sfide della modernità (Nápoles, diciembre de 2018), también se presentó el trabajo "Gli attentati popolari contro il Borbone: iconoclastia e progetti di tiranicidio (Regno delle Due Sicilie, 1848-1860)", realizado por Pierre-Marie Delpu. Véase asimismo el reciente dossier Iconoclastia nel lungo Ottocento, en Memoria e ricerca, $\mathrm{n}^{\circ}$ 57, 2018.

9 Bernard Richard, Les emblèmes de la République, CNRS Éditions, Paris, 2012, p. 23.

10 Emmanuel Fureix, "Effacer la République: un iconoclasme contre-révolutionnaire (17991852)", en Gerard Monnier y Évelyne Cohen (dir.), La République et ses symboles. Un territoire de signes, Publications de la Sorbonne, Paris, 2013, p. 53.
} 
reales, su difusión y lo que pretendian transmitir ${ }^{11}$. El precedente más conocido de destrucción masiva de símbolos monárquicos en la Europa contemporánea había sido el ocurrido durante la Revolución Francesa, singularmente en $1792^{12}$. Seguro que en la España de 1868 algo sabían de ello quienes participaron en La Gloriosa, siquiera entre las élites más leídas.

Lo primero que debe aclararse es que la mayoría de los episodios iconoclastas del 68 se desencadenan cuando se tienen noticias del triunfo de la revolución, por lo que no fueron tanto una parte de los movimientos que condujeron a la caída de Isabel II como una celebración de ese desenlace, aun cuando se hayan documentado casos anteriores a la batalla de Alcolea y al exilio de la reina. También conviene inscribirlos en una secuencia histórica. No hacía tanto que el ahora execrado retrato de Isabel II había desempeñado un papel simbólico medular, llegando incluso a ser glorificado durante la revolución de 1854, cuando terminó siendo exhibido en algunas barricadas al lado del de Espartero y otros, "como iconos de mágica influencia"13. La destrucción de lápidas, bustos y retratos, que encerraban una lucha por dominar simbólicamente los espacios públicos, tenía sus precedentes en épocas anteriores. Son bien conocidas las pugnas del Trienio Liberal, cuando también se dieron actos muy simbólicos y ritualizados - tanto por simpatizantes como por detractores - en torno a las lápidas que decian "Plaza de la Constitución"14. Tales episodios pretéritos se recordarian a lo largo de todo el siglo XIX; incluso otros anteriores, como los protagonizados por los estudiantes de Salamanca en mayo de 1808, cuando destruyeron el busto de Godoy de la Plaza Mayor y el del ministro Pedro Ceballos de la Universidad ${ }^{15}$. De hecho, la quema de retratos del valido se ha documentado en muchas ciudades ${ }^{16}$.

11 Roger Chartier, Les origines culturelles de la Révolution française, Éditions du Seuil, Paris, 2000, p. 190-193.

12 Edmond y Jules de Goncourt, Histoire de la société française pendant la révolution, Didier et Cie Libraires-Éditeurs, 1875 ( $4^{\mathrm{a}}$ ed.), p. 270 y ss. Sobre las estatuas reales, Lynn Hunt, "L’iconoclasme et le temps en révolution", en Emmanuel Fureix (dir.), Iconoclasme et révolutions. De 1789 à nos jours, Champ Vallon, Ceyzérieu, 2014, pp. 53-56.

13 En palabras de Francisco Pi y Margall y Francisco Pi y Arsuaga, Historia de España en el siglo XIX, Tomo IV, Miguel Seguí Editor, Barcelona, 1902, p. 90.

14 Demetrio Castro Alfin, "Simbolismo y ritual en el primer liberalismo español", en José Álvarez Junco (comp.), Populismo, caudillaje y discurso demagógico, Madrid, Centro de Investigaciones Sociológicas, 1987, pp. 287-317.

15 Enrique Rodríguez Solís, Historia del Partido Republicano Español. De sus protagonistas, de sus tribunos, de sus héroes y de sus mártires, tomo II, Imp. de Fernando Cao y Domingo de Val, Madrid, 1893, p. 57.

16 Antonio Moliner Prada, Revolución burguesa y movimiento juntero en España. La acción de las juntas a través de la correspondencia diplomática y consular francesa, 1808-1868, Milenio, Lleida, 1997 , pp. 42 y 54. Sobre este asunto y el valido en general, véase la completa biografia de Emilio La Parra, Manuel Godoy. La aventura del poder, Tusquets, Barcelona, 2002; autor a quien también agradezco que me sugiriese el trabajo específico de Isadora Joan Rose Wagner, "La celebrada caída de nuestro coloso". Destrucciones espontáneas de retratos de Manuel Godoy por el populacho", Academia. Boletín de la Real Academia de Bellas Artes de San Fernando, n 47, 1978, pp. 197-226. En cualquier caso, evitaremos hacer aquí más consideraciones sobre estos precedentes que, a grandes rasgos, redundarian en lo que ya explica muy bien el artículo de Marie-Angèle Orobon y José Luis González Fernández en este mismo dossier. 
Lo que se produce en 1868 puede considerarse un intento de damnatio memoriae $^{17}$. Pero, sobre todo, representó en primera instancia un destronamiento simbólico: un verdadero derrocamiento figurado ${ }^{18}$. Cuando un rey accedía al trono, su efigie circulaba en monedas y sellos, exhibiéndose hasta en los lugares más apartados del reino ${ }^{19}$; se trataba además, en este caso, de una monarca "extensamente retratada" cuyo reinado conoció la eclosión de la fotografía ${ }^{20}$. En tales circunstancias, si la soberana abdicaba o era destronada, lo esperable es que se diera el proceso inverso, de forma tanto más estrepitosa cuanto menos popular hubiera resultado su reinado. Y esto, de hecho, ocurrió en muchos lugares al mismo tiempo y ajustándose a rituales muy parecidos. Tales episodios de iconoclasia ubicua, en resumen, deben interpretarse como destronamientos simbólicos a escala local o remedos del derrocamiento que trajo consigo Alcolea, entre otras razones porque, más allá de la lectura que pudiera hacerse actualmente desde la historia cultural o la antropología politica, lo cierto es que esta interpretación ya subyace en algunos testimonios de la época que así lo percibieron. Basta con recordar el de Palacio Valdés cuando afirma que vio "cómo derrocaban el busto de bronce de la reina"21. Figurada o metafóricamente, pues, el hecho de suprimir la imagen equivalia a destronar a la persona que representaba, aparte de mancillarla y despojarla del aura de sacralidad que venía rodeándola.

De modo que la iconoclasia de 1868 fue algo más que un desahogo popular. Ahora bien, no hay que ignorar que la puesta en escena se reveló también muy efectiva para la movilización de las clases medias y los sectores populares

17 No puede considerarse plena, sino -en todo caso- un intento o conato; por diversas razones, como se argumenta en Sergio Sánchez Collantes, "Limitaciones de la iconoclasia política de 1868 en España: paradojas, obstáculos y pervivencias ante la destrucción simbólica", en Rosana Gutiérrez Lloret y Renata de Lorenzo (eds.), Las monarquías de la Europa meridional y los retos de la modernidad, Prensas Universitarias de Zaragoza, 2019 (en prensa). Algunos matices sobre la relación entre la iconoclasia (o las iconoclasias) y la damnatio memorie, en Emmanuel Fureix, "Introduction", en Emmanuel Fureix (dir.), Iconoclasme et révolutions. De 1789 à nos jours, Champ Vallon, Ceyzérieu, 2014, p. 23; también "Iconoclastia e Restaurazione: epurare il passato, scongiurare la guerra civile (Francia, 1814-1830)", Memoria e ricerca, n 57, 2018, pp. 45-60.

18 Recupero y desarrollo aquí una expresión e idea utilizadas en Sergio Sánchez Collantes, "“iAbajo las testas coronadas!". Los bustos como símbolo del cambio político en 1868", Atlántica XXII. Revista asturiana de información y pensamiento, $\mathrm{n}^{\circ}$ 42, 2016, pp. 54-56; en "La construcción simbólica del republicanismo español en el Sexenio Democrático", Investigaciones Históricas, época moderna y contemporánea (IH), $\mathrm{n}^{\circ}$ 37, 2017, pp. 132-174 (p. 136-137); y en "Luchas simbólicas por el espacio público en el Sexenio Democrático: republicanos y monárquicos en las calles españolas, 1868-1874", Crisol. Serie numérique, $\mathrm{n}^{\circ}$ 5, Université Paris Nanterre, 2019, pp. 203-219 (p. 205).

19 Cuando se daba un cambio de régimen, es muy elocuente la rapidez con la que un pueblo minúsculo adquiria las preceptivas imágenes en consonancia con la nueva situación para que luciesen en los edificios públicos (ayuntamientos, escuelas, etc.). Un ejemplo de esa mudanza para 1868 y 1875 en una población de aproximadamente un millar de habitantes, en Sergio Sánchez Collantes: "El siglo XIX en Tudelilla", en Penélope Ramírez Benito (ed.), Tudelilla: un recorrido histórico (1684-1979), Instituto de Estudios Riojanos, Logroño, 2016 p. 170.

20 Que sirvió, por ejemplo, para difundir masivamente la imagen real mediante las tarjetas de visita, como explica Rafael Gil Salinas, "La imagen de la Reina Isabel II y la fotografia", Millars. Espai i Història, n 16,1993 , pp. 52-54.

21 Armando Palacio Valdés, La novela de un novelista. Escenas de la infancia y adolescencia, Espasa-Calpe, Madrid, 1959, p. 212. 
urbanos, cuyo concurso resultaba esencial para el triunfo de la revolución en todo el país. Además, como bien interpreta Gregorio de la Fuente, el hecho de arrastrar por las calles un objeto que representase a Isabel II no sólo servia "para enterar a la gente de su irremediable final" sino también para que esa misma gente "manifestase públicamente su repulsa a la ex Reina y su adhesión a la revolución" 22 . En este sentido, era asimismo una forma de solemnizar la victoria "con demostraciones jubilosas"23. La efectista escenificación que acompañó los múltiples destrozos, por tanto, cumplia una función polivalente, con diversas facetas entrecruzadas que interesa observar simultáneamente.

No está de más recordar, además, que la iconoclasia constituyó precisamente la principal válvula que ayudó a canalizar la violencia en aquellos primeros momentos: se dirigió contra los símbolos en distintos soportes, y raras veces contra las personas. Joaquín Costa lo escribió en su diario el 5 de octubre: "La revolución se ha hecho casi sin sangre"24. La propia Eulalia de Borbón, que estaba con Isabel II cuando triunfó la revolución y emigraron a Francia, hizo alguna consideración al respecto: "se comenzaron a tomar precauciones para impedir que nuestras vidas se vieran en peligro, aunque jamás mi madre temió una crueldad por parte de sus levantiscos súbditos" 25 . A propósito de esta característica de la revolución del 68, el que se produjera "sin derramamiento de sangre", ha reflexionado Gregorio de la Fuente, que considera que hubo una táctica mixta de pronunciamiento y alzamiento por la colaboración de elementos militares y civiles; y que seguramente los primeros "buscaron el concurso de los grupos de paisanos como garantía de un triunfo incruento". Aun señalando alguna excepción ${ }^{26}$, dicho autor reconoce que "la voluntad de no causar bajas innecesarias fue común a ambos contendientes y permitió realizar el cambio politico de forma relativamente incruenta", por lo que la revolución de 1868 puede considerarse "un caso benigno, comparada con la violencia desatada en otros cambios políticos drásticos de la España del XIX, y explica que se le atribuyera el adjetivo de Gloriosa, en recuerdo de la pacífica transformación inglesa de 1688 "27.

Al tratarse de un levantamiento que se dirigia contra lo anterior, Isabel II devino el gran símbolo de un régimen que se reputaba caduco, por lo que sus

22 Gregorio de la Fuente Monge, Los revolucionarios de 1868, op. cit., p. 101.

23 Dicho en palabras de Emilio Gutiérrez Gamero, Mis primeros ochenta años (Memorias), Tomo I, Madrid, Aguilar, 1962, p. 234.

24 Joaquín Costa, Memorias, Prensas Universitarias de Zaragoza-Institución Fernando el Católico, Zaragoza, 2011 , p. 88.

25 Memorias de Eulalia de Borbón. Infanta de España, Editorial Juventud, Barcelona, 1987 [1935], p. 11

26 Dicho autor recuerda, por ejemplo, la "represión civil efectuada por las tropas gubernamentales durante su frustrada toma de Béjar" (Gregorio de la Fuente Monge, Los revolucionarios de 1868, op. cit., p. 17). Podrian añadirse más. En sus memorias, Rodríguez Solís menciona "la muerte de dos infames polizontes, el "Estanquero" de la plaza de Antón Martín y el "Bollero" de la calle del Olivo", a manos de unos milicianos, explicando el hecho por sus antecedentes: "Crueles, inhumanos, habían perseguido a los liberales, los habian apaleado, los habian encarcelado, destruyendo sus honrados y tranquilos hogares". Véase Enrique Rodriguez Solís, Memorias, Editorial Plutarco, Madrid, 1931, p. 117.

27 Gregorio de la Fuente Monge, Los revolucionarios de 1868, op. cit., p. 17-18. 
imágenes y las de su dinastía, los emblemas Iato sensu de aquella monarquía lato sensu, se convirtieron en el objetivo predilecto de la iconoclasia en muy pocos dias y a veces en cuestión de horas. Las escenas más espectaculares tuvieron como protagonistas los retratos y bustos. Decenas de testimonios escritos describen los acontecimientos, pero también existe documentación gráfica del mayor interés que, en forma de grabados o caricaturas, recogen ese momento histórico. Por añadidura, es interesante constatar que tales episodios se recordaban mucho tiempo después.

\section{Figura 1.- Escena paradigmática de la iconoclasia antiborbónica}

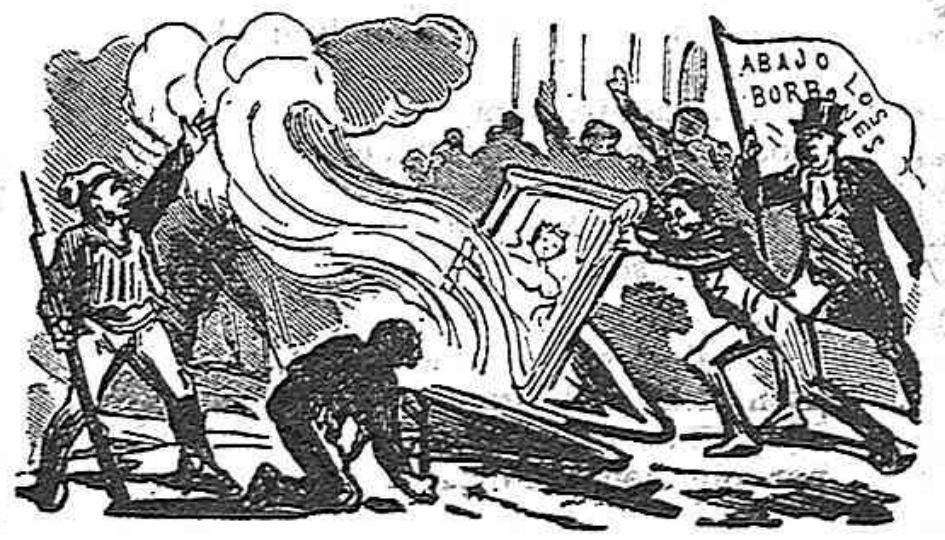

Fuente: La Campana de Gracia, 26-IX-1908. Se observa cómo arde el retrato de Isabel II en la hoguera y, al fondo, alguien ondea la bandera con el lema "abajo los Borbones".

En los libros de memorias de quienes vivieron aquellos hechos, esa destrucción de bustos y retratos suele aparecer de forma recurrente como algo que impresionó mucho a las personas que lo vivieron. A Santiago Ramón y Cajal, por ejemplo, le sorprendió con 16 años cuando vivía en el pueblo oscense de Ayerbe, que entonces apenas sumaba 600 habitantes. Recuerda que "una inquietud extraña pareció apoderarse de los vecinos" y también que se leían "públicamente incendiarias proclamas revolucionarias $y$ se oían vítores entusiastas a Serrano, Topete, y sobre todo a Prim". Y en lo que se refiere a la iconoclasia, presenció una escena muy similar a la de otros muchos lugares:

"Con las calientes notas del himno de Riego, incansablemente ejecutado por la citada banda, alternaban entusiastas aclamaciones a los caudillos de la revolución. Un grupo de sublevados arrancó de las escuelas el retrato de Isabel II, quemándolo en la plaza, entre las rechiflas y denuestos de plebe alborotada"28.

He aquí una expresión, la de "plebe alborotada", que cabría sumar a las que solian emplearse para referirse despectivamente a las acciones colectivas y las protestas emprendidas por la gente del común. Un fenómeno en el que ya reparó G. Rudé al estudiar los casos francés y británico, donde observó el socorrido estereotipo consistente "en aplicar la etiqueta de "turba" o "populacho", sin discriminación, a todos los participantes de los disturbios populares" (Burke llegó

28 Santiago Ramón y Cajal, Recuerdos de mi vida. Primera parte. Mi infancia y juventud, Imprenta de Juan Pueyo, Madrid, 1923, p. 96. 
a hablar de "cochina multitud" y Taine de "hez de la sociedad")29. Muchos, pues, despreciaron a los ejecutores de la iconoclasia como simple "chusma".

Ahora bien, la destrucción de los emblemas que representaban la situación anterior fue casi una necesidad de quienes secundaban a los revolucionarios. ¿Acaso no se gritaba “¡abajo los Borbones!” y “¡abajo lo existente!”? ¿no decían eso las proclamas y las hojas volantes? A las pocas horas de conocer la derrota de la reina, gente como Nicolás Estévanez defendía sin rebozo "que sería bueno quemar ciertos simbolos y cachivaches"30. Formaba parte de la "fiesta revolucionaria" descrita por Gregorio de la Fuente ${ }^{31}$, con una primera fase más popular que, a partir de cierto momento, se institucionaliza. La feliz expresión acuñada por Ozouf en su citado ensayo sobre la Francia de 1789-1799 podríamos reformularla, para el fenómeno que aquí examinamos, y hablar de una paralela fiesta o celebración iconoclasta. Había sobre el tapete un listado de demandas populares a las que dar satisfacción, y muchas quedarian finalmente insatisfechas, pero la posibilidad de expansionar y solazarse cebándose con las representaciones borbónicas durante unas horas; saciar esas ganas de transgredir, en definitiva, profanar los emblemas reales de una forma que habría resultado impensable pocos dias antes, era un anhelo bien fácil de conceder. Si en otras circunstancias se procuró acercar la Monarquía al pueblo, ahora se hacía lo propio con su caída, que de esta forma se hacia tangible a escala local.

La destrucción de los símbolos asociados a la monarquía borbónica cumplía una función movilizadora desde el punto de vista de los partidarios de la revolución, y en su transcurso se forjaron liderazgos que tendrian vigencia duradera. No hay que olvidar que la intervención del elemento civil le dio a La Gloriosa su particular esencia y garantizó el triunfo al reclutar a sectores agraviados que, a su vez, eran usados por las nuevas autoridades para legitimarse: como bien explica Gregorio de la Fuente, el hecho de quemar un retrato de Isabel II "sólo podía ser interpretado por los políticos como una forma festiva de manifestar su apoyo a la junta revolucionaria", por lo que, en la práctica, "cumplía la misma función que la "aclamación popular""32. Además, apelando al sentimiento y la emoción, se lograba transitoriamente concitar el apoyo de quienes, en realidad, estaban alineados con proyectos y horizontes políticos divergentes e incluso antagónicos. La furia iconoclasta facilitó, en ese sentido, un consenso minimo en torno a lo que encarnaba La Gloriosa y los símbolos que había que suprimir. El grito de “¡abajo los Borbones!" ejerció un magnetismo aglutinador coyuntural, sujeto a las circunstancias de aquel momento histórico tan preciso en el que un monárquico demócrata, un republicano, un federal de los que pronto se llamarán intransigentes y hasta un internacionalista en ciernes podian aplaudir gozosos, en una misma plaza, el hecho de que un lienzo con la efigie de Isabel II fuese devorado por las llamas.

29 George Rudé, La multitud en la historia. Los disturbios populares en Francia e Inglaterra, 1730 1848, Siglo XXI Editores, Madrid, 1998, pp. 15-16.

30 Nicolás Estévanez, Mis memorias, Tebas, Madrid, 1975 [1903], p. 161

31 Gregorio de la Fuente Monge, Los revolucionarios de 1868, op. cit., p. 92 y ss.

32 Gregorio de la Fuente Monge, "La revolución de 1868 y la continuidad del personal politico", Ayer, no 29, 1998, pp. 168-170. 
Tampoco hay que subestimar, como estimulo para la imitación en determinados lugares, el efecto que podría haber tenido la publicación de noticias en la prensa de gran tirada. Al respecto, es importante recordar que hasta las cabeceras extranjeras comunicaron los brotes iconoclastas que se estaban produciendo, y con bastante rapidez. En su número del 4 de octubre de 1868, por ejemplo, el diario Le Gaulois ya informaba sobre el particular. Además, curiosamente, no juzgaba que la destrucción de símbolos borbónicos fuese una alteración del orden:

"Le pronunciamiento de Barcelonne a eu lieu sans provoquer aucun désordre. Le peuple s'est borné à détruire jusqu'au dernier vestige de la royauté bourbonienne, écussons et chiffres, statues et portraits d'Isabelle II"33.

\section{LA ESCENIFICACIÓN LOCAL DEL FINAL DE UN RÉGIMEN}

Para conocer lo que ocurrió aquellos días y algunas características del fenómeno iconoclasta, nada mejor que examinar una serie de hechos documentados en una selección de ciudades de tamaño variable y localización geográfica diversa ${ }^{34}$.

En la mayor parte de los casos, la destrucción se efectuó recurriendo a una puesta en escena ostentosa, en la que se buscaba lo espectacular y, apelando a las emociones, se procuraba el concurso visceral de unas masas que, eufóricas, se adueñaban de los espacios públicos al grito de "jabajo los borbones!". Aunque no sigamos un orden cronológico, debe tenerse en cuenta la secuencia de los acontecimientos que fueron extendiendo la revolución iniciada en Cádiz por Andalucía y por el resto de España: a partir del 29 de septiembre, la iconoclasia se va a generalizar y se observa mayor simultaneidad, pero en algunas provincias el fenómeno se adelantó conforme triunfaba la causa revolucionaria. En Málaga, por ejemplo, los primeros casos se dieron ya el 21 de septiembre, cuando los retratos de Isabel II que había en las oficinas del Ayuntamiento, junto con otros objetos y muebles, "fueron hechos pedazos" y "arrojados por los balcones", al mismo tiempo que los guardias eran "atropellados y golpeados, huyendo entre el bullicio"35.

En Barcelona, como el palacio de la Diputación provincial y el balcón principal del Consistorio daban a la misma plaza de Sant Jaume, resultó muy espectacular la hoguera que se formó con varios retratos de la monarca de ambos edificios, además de "los sillones, doseles, tablados y demás atributos del trono"36. La multitud entró en el palacio de la diputación y lanzó por la ventana la

33 Le Gaulois, París, 4-X-1868. "El pronunciamiento de Barcelona ha tenido lugar sin causar ningún desorden. / El pueblo se limitó a destruir el último vestigio de la realeza borbónica, escudos y figuras, estatuas y retratos de Isabel II".

34 Se trata sólo de una muestra a la que podrían sumarse otros casos. Véase, por ejemplo, el listado de referencias adicionales que se facilita en Gregorio de la Fuente Monge, Los revolucionarios de 1868, op. cit., p. 101, n. 61.

35 Narciso Díaz de Escovar, De la vieja Málaga, s.e,, s. 1., s. p.

36 M. M. de Lara, El cronista de la revolución española de 1868. Narración fiel de todos los sucesos que componen el glorioso movimiento, con todos los documentos oficiales que se han publicado durante su curso hasta la constitución del gobierno provisional, Imprenta de Celestino Verdaguer, Barcelona, 1869, p. 110. En su relato, absolutamente parcial, sentencia el autor: “¡Brillante lección para las testas coronadas! Así es como aprenden los reyes a saber lo que son y 
estatua de la reina que presidía el salón de sesiones. La agitación ya había empezado cuando el 29 de septiembre llegaron noticias del levantamiento de Madrid, oyéndose "vitores a la soberanía nacional y mueras a la dinastia". Más tarde, se produjeron las escenas que nos interesan y que evoca Conrado Roure en sus memorias:

"Retiróse el conde de Cheste de las Ramblas y entonces las masas dirigiéronse a la plaza de la Constitución, encendieron una gran hoguera y a ella lanzaron cuadros y atributos referentes a lo que fuera causa de aquella revuelta nacional.

Y lo mismo que efectuaron en la plaza de la Constitución realizáronlo también en la plaza Nueva, quemando emblemas similares que habia en la casa del obispo, y en el Llano de la Boquería efectuaron otro tanto con unos cuadros que había en el Liceo de Isabel II.

Al tiempo que se efectuaban estos autos de fe, del Ayuntamiento salió una manifestación llevando desplegadas las banderas de los cuerpos de la milicia y un retrato del general Prim, que llevaban en andas" 37 .

\section{Figura 2.- La multitud incendia simbolos borbónicos en Barcelona}

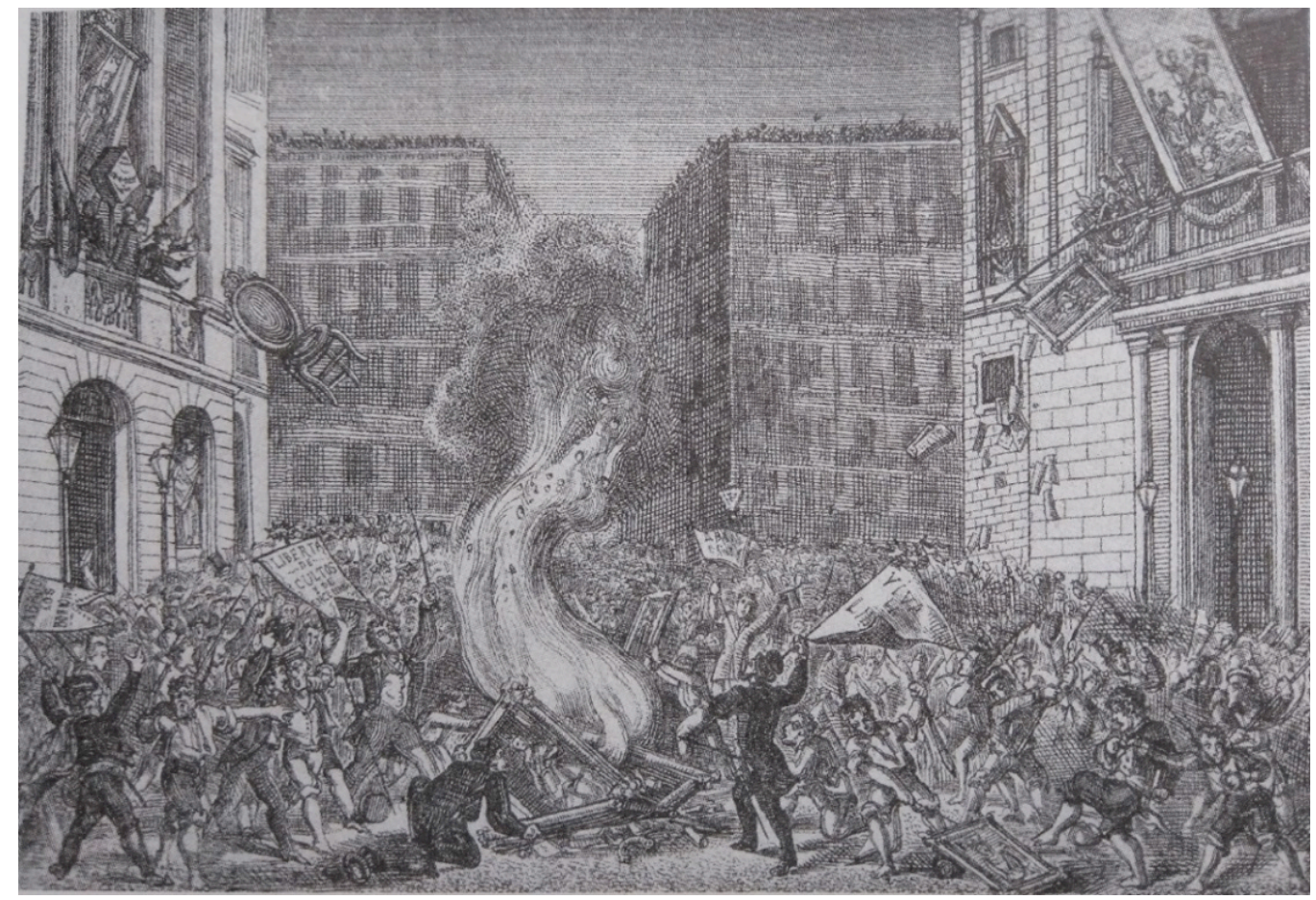

Fuente: grabado reproducido - entre otros sitios - en Conrado Roure, Recuerdos de mi larga vida, tomo III, Imp. de Domingo Garrofé, Barcelona, 1927, p. 101. En la escena se aprecian diversos retratos y los sillones con el escudo, junto con otros objetos que son arrojados a la plaza desde las ventanas.

El busto que presidía la escalera principal del Liceo fue arrastrado Rambla abajo hasta el mar. Milagrosamente sobrevivió, aunque con daños importantes, ya que perdió la nariz, y hoy se conserva en los fondos del Museu Nacional d'Art

lo que valen los pueblos. Ayer contempló Barcelona un acto que jamás presenciaron sus hijos, un acto que ejerció el pueblo en uso de su soberanía; el destronamiento de un rey".

37 Conrado Roure, Recuerdos de mi larga vida, tomo III, Imp. de Domingo Garrofé, Barcelona, 1927, p. 100. 
de Catalunya ${ }^{38}$. La puesta en escena va a ser muy similar en otros puntos de la región y de España, tanto el lanzamiento de las imágenes desde el balcón de los edificios institucionales como su traslado y exhibición por las calles de la localidad invitando al prójimo a sumarse a la comitiva. En Sabadell, por ejemplo, se dio igualmente esa "violencia simbólica" contra los retratos de la reina, que fueron arrojados desde el balcón junto con tallas de las quintas, libros y sillones $^{39}$. Y sobre Arenys de Mar, dijeron las crónicas periodísticas:

"Un gran número de pueblo se presentó en la Casa Consistorial y se nombró una junta, se tiró a la calle el retrato de Isabel de Borbón, y fue quemado; recorrió las calles de la villa al sonido de la orquesta que tocaba la marcha o himno de Riego intercalada con vivas a la libertad, a Prim, etc., y mueras a los Borbones: ningún desmán, ni menos insulto alguno, amenguó la expansión de este siempre morigerado pueblo" 40 .

No es ocioso recordar aquí las connotaciones añadidas de los brotes iconoclastas en esa región, donde también han sido relacionados con la politización del catalanismo y con "el sentimiento antiborbónico ligado al recuerdo del decreto de Nueva Planta". En Barcelona, por ejemplo, se quemó asimismo el retrato de Felipe $\mathrm{V}$ y, aunque fuese más excepcional, hubo efectivamente casos de reivindicaciones políticas de tipo historicista sobre las libertades suprimidas con la llegada de esta dinastía ${ }^{41}$.

En Madrid, como resume Fuente Monge, se destruyeron los retratos de Isabel que había en Gobernación y, en general, fueron "rotos y pisoteados" los escudos con las armas reales de los edificios públicos, aparte de los de algunos establecimientos. Incluso los militares que confraternizaban con la multitud arrancaron de sus uniformes las coronas y las iniciales de Isabel II. En el fresco de la puerta del convento de las Calatravas rasparon y escupieron la cara del rey consorte Francisco de Asís, a quien se representa adorando a la Virgen ${ }^{42}$. Es importante subrayar que los propios historiadores contemporáneos a los hechos los consideraron lo suficientemente trascendentales como para mencionarlos en sus obras de referencia. Francisco Pi y Margall e hijo, por ejemplo, recuerda lo sucedido en el consistorio madrileño:

"Don Nicolás María Rivero se puso en la calle de Santa Isabel al frente de unos cuantos paisanos armados, y con ellos se dirigió al ayuntamiento, cuyas puertas le fueron franqueadas en el acto. El gentío que se reunió en el salón de sesiones de la Casa de la Villa y en la Calle Mayor, era tan grande, que no había medio de entenderse. Rivero, entonces arrancó el retrato de Isabel II, que figuraba bajo dosel en el testero del salón, lo arrojó por el balcón a la calle, invitando al pueblo a arrastrarlo. Estalló la multitud en entusiasmo. Los grupos corrieron de una parte a otra dando gritos de ¡Viva la libertad y abajo los Borbones! De las muestras de las

38 El Periódico, Barcelona, 7-XI-2017.

39 Josep. M. Benaul Berenguer, "Política i consums. La revolució del 1868 a Terrassa", Recerques. Història, economia i cultura, $\mathrm{n}^{\circ}$ 17, 1985, p. 91 (el trabajo se centra en Tarrasa pero contiene esa referencia a Sabadell).

40 La Esperanza, Madrid, 3-X-1868.

41 Pere Anguera Nolla, "La politización del catalanismo", Ayer, n 44, 2001, pp. 34-35.

42 Gregorio de la Fuente Monge, Los revolucionarios de 1868, op. cit., p. 100. 
tiendas de proveedores de Palacio y de todos los edificios públicos, fueron arrancadas y pisoteadas las coronas. El pueblo se declaraba antidinástico" ${ }^{43}$.

\section{Figura 3.- Quema de retratos de Isabel II y de Felipe V en Barcelona}

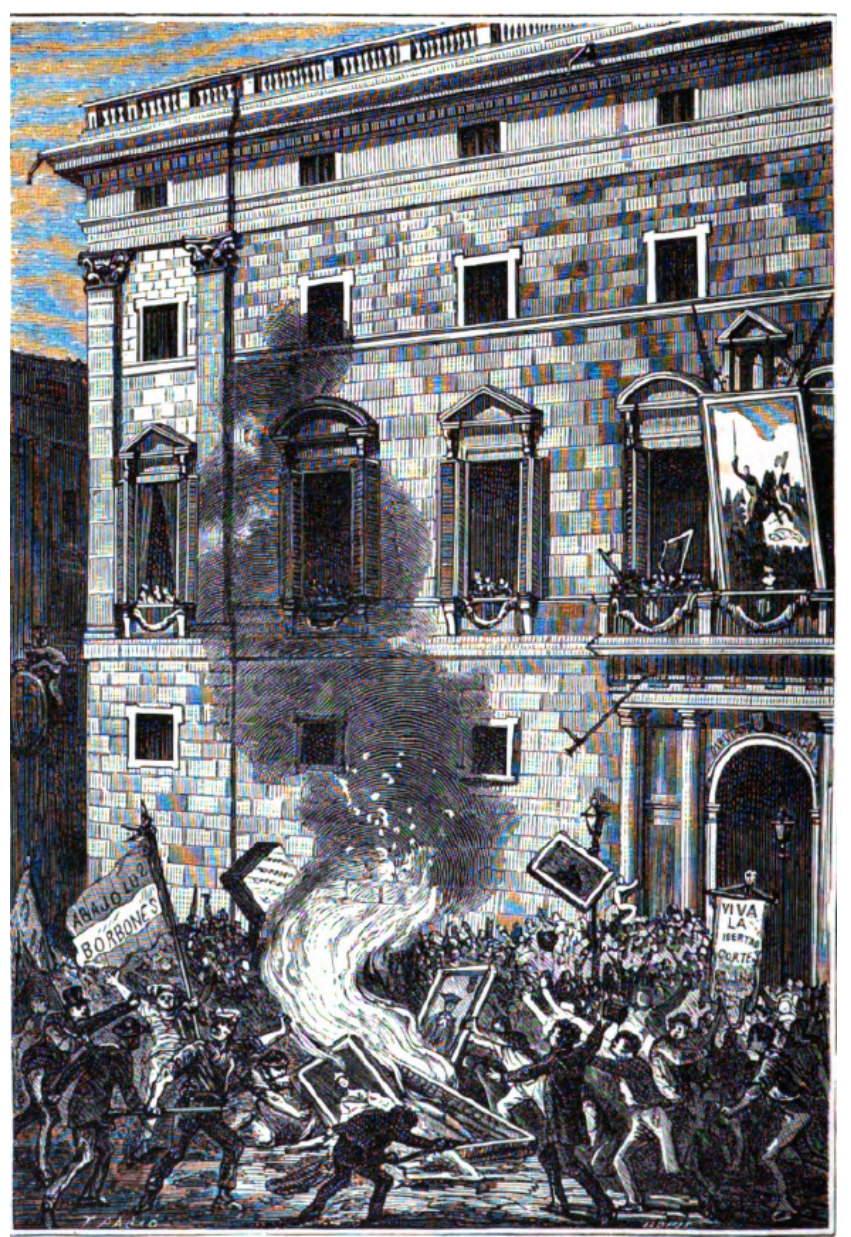

Fuente: lámina de Fernando Garrido, Historia del reinado del último Borbón de España, Tomo III, Barcelona, s.e., 1869, entre pp. 1206-1207. Al pie de la imagen se lee "El pueblo de Barcelona quemando los retratos del primero y último Borbón de España". Se distingue también la bandera con la consigna "abajo los Borbones".

Hay que destacar la relevancia de esas "invitaciones" que buscaban la adhesión de los presentes haciéndoles partícipes, y que no estaban exentas de intimidación para quien no simpatizase con demostraciones tan viscerales. Hay testimonios que hablan de retales de lienzos con la efigie de la reina que, tras ser rotos o quemados, fueron "puestos en las puntas de los palos y paseados por las calles para que todos los escupiesen"44. Es una puesta en escena que resulta dificil no asociar con las picas de los sans culottes, y había mucho de sacrilegio en semejante representación. Esa forma de proceder resultaba a menudo muy teatral, como ilustra el tratamiento

43 Pi y Margall y Francisco Pi y Arsuaga, Historia de España en el siglo XIX, IV, op. cit., p. 135. Del cuadro, afirmó M. M. de Lara, El cronista de la revolución española de 1868, op. cit., p. 110: "en pocos minutos desaparece hecho pedazos".

44 Gregorio de la Fuente Monge, Los revolucionarios de 1868, op. cit., p. 101. El autor también subraya que muchos grupos iban a menudo armados, así que quienes desaprobaban los actos solian encerrarse en casa para evitar problemas. 
que recibió el óleo de Isabel II que había en la sala capitular del Ayuntamiento de Guadalajara, que fue descolgado por "un grupo de ciudadanos [...], y después de asestarle varias puñaladas un tabernero [...], lo arrojó desde la galería a la plaza, donde las turbas intentaron acabar la obra destructora" 45 . O en el pueblo tarraconense de Poboleda, donde los cuadros fueron primero "fusilados en las tapias del cementerio y luego quemados en presencia de la gente" 46 . También en Barcelona se vivieron escenas parecidas, y hubo un momento en que la multitud se ensañaba con las imágenes en distintos puntos y de formas variopintas: "rasgándose, escupiéndose, pisoteándose y quemándose el retrato de aquella ingrata señora que poseían respectivamente el Obispo de esta diócesis y la Junta de gobierno del teatro del Liceo"47. Para todos los supuestos mencionados, podría extrapolarse la lectura que hace Demetrio Castro de la guerra de lápidas y la querella simbólica de los años 1820-1823, afirmando que el simbolismo politico del retrato "no se manifiesta sólo en la veneración de que es objeto por parte de sus adictos, sino en la vejación, también ritualizada, por sus detractores" 48 .

El protagonismo republicano en dichas escenificaciones es claro, aunque no exclusivo, ni siquiera si nos limitamos a los protagonistas más implicados. En Valladolid, por ejemplo, fue un respetable boticario progresista, Ángel Bellogín, quien remató su discurso arrojando el busto desde el balcón del gobierno civil, ante una plaza rebosante que celebró exultante esta determinación. Y también era progresista el catedrático de medicina Eugenio Alau, quien, desde el balcón del Ayuntamiento de la misma ciudad, al terminar el primer discurso de los revolucionarios, echó mano de un cuadro de Isabel II y lo "redujo, con nerviosos puños, a pequeños jirones, dejándolos caer sobre la muchedumbre, con frases de execración a la dinastía destronada"49. La prensa de Madrid ya resumía el día 3 lo ocurrido en Valladolid en materia de símbolos y emblemas: "Los retratos de doña Isabel de Borbón que se hallaban colocados en la casa Consistorial y oficinas públicas de Valladolid, han sido rotos, lo mismo que los escudos de armas reales que habia en los estancos y otros establecimientos" 50 . Incluso en pueblos diminutos de la provincia se documentan quemas, como la de pendones y otros objetos empleados en las funciones religiosas organizadas para aclamar a los monarcas ${ }^{51}$.

Si en ciertas actuaciones en edificios o en dependencias religiosas podrian verse ribetes anticlericales, lo cierto es que no faltan episodios que maticen la existencia de una de iconoclasia religiosa o que limiten su impacto, como se puso de manifiesto en Logroño si hacemos caso de la versión que dio la prensa. El

45 Luis Cordavias, La monja de las llagas. Vida de Sor Patrocinio, Sucesores de Antero Concha, Guadalajara, 1917, pp. 114-115. Debo la localización de este testimonio a la referencia hecha en la citada obra de Fuente Monge y a la indicación contenida en Rafael Villena Espinosa, "La revolución tranquila: el despliegue de la Gloriosa en la España interior", Ayer, n 112, 2018 , p. 61.

46 Gregorio de la Fuente Monge, Los revolucionarios de 1868, op. cit., p. 101.

47 M. M. de Lara, El cronista de la revolución española de 1868, op. cit., p. 110.

48 Demetrio Castro Alfin, "Simbolismo y ritual en el primer liberalismo español”, op. cit., p. 307.

49 Gregorio de la Fuente Monge, Los revolucionarios de 1868, op. cit., pp. 99-100 y 110.

50 La Correspondencia de España, Madrid, 3-X-1868.

51 Federico Carbonero, Historia de la Nava del Rey, Imprenta y Librería de F. Santarén Madrazo, Valladolid, 1900, p. 34. 
emblemático día 29 de septiembre, un mozo de la estación de ferrocarril "capitanea las masas" que van a casa del gobernador militar "y todos sus muebles arden", y lo mismo en la del gobernador civil ("cuanto hay en ella es consumido por el fuego"), pero en el primer caso se da una situación llamativa:

“[...] recibe un cuadro para echarlo a la hoguera. Lo mira, ve en él la imagen de Jesucristo, y grita: "Esto no se quema; ¡viva Cristo!», palabras mágicas que encuentran un solo eco en todos los circunstantes. El cuadro, intacto y llevado en triunfo, es depositado en el ayuntamiento, que lo coloca en el lugar preferente"52.

Al respecto, parecen también reveladoras las palabras del diputado carlista Ramón Vinader cuando, en las Cortes de 1869, evocó aquellas "turbas embriagadas con la revolución y la victoria [que] recorrian las calles derribando las coronas reales que hallaban al paso, y al acercarse a las Calatravas, tratando de borrar un retrato del marido de doña Isabel de Borbón, que en un cuadro está pintado ofreciendo el proyecto de la obra a la madre de Dios, hiciéronlo con cristiano cuidado, para no profanar el rostro de la Virgen inmaculada" 53 . Pero no siempre fue así, porque a mediados de octubre se quemó un retrato del Papa en una plaza de Barcelona y un ejemplar del Concordato en Madrid, frente al palacio del nuncio, hechos de los que incluso se hizo eco la prensa francesa ${ }^{54}$.

\section{Figura 4.- Busto en mármol de la reina Isabel II}

Fuente: Biblioteca Virtual de Defensa, obra del escultor E. Panini conservada en el Museo del Ejército, Colección ES-DFMMUE, $\mathrm{n}^{\mathrm{o}}$ inventario MUE-30861. Disponible en: http://bibliotecavirtualdefensa.es/BVMDefensa/i18n/consulta/registro.cmd?id=17081 [con acceso el 9-I2019]

52 El Pensamiento Español, Madrid, 9-X-1868. La Esperanza, Madrid, 10-X-1868.

53 Diario de Sesiones de las Cortes Constituyentes, 23-II-1869, p. 129. Lo dijo para criticar al Gobierno por sus politicas, que en su opinión atacaban lo que el pueblo había respetado.

54 Le Gaulois, París, 15-X-1868. Del incidente del concordato informó La Época, 9-X-1868, citando El Imparcial. 
En el palacio del Temple de Valencia también fue un representante del progresismo, José Peris y Valero - principal dirigente en la ciudad y presidente de la junta revolucionaria de la provincia-, quien arrancó la flor de lis de la bandera y tiró desde el balcón un busto de Isabel II, para júbilo de unos asistentes que "llegan al delirio" pisoteando los restos de la marmórea efigie mientras pedian que sonara el Himno de Riego ${ }^{55}$. La música, en efecto, solía realzar la escenificación, que se desarrollaba en medio de cánticos patrióticos que, en muchos casos, acabaron patrimonializados por quienes rechazaban toda solución monárquica, en manifestaciones diseñadas para conseguir una republicanización física y acústica del espacio público ${ }^{56}$. Peris y Valero, por cierto, será quien un año después, como presidente de la Diputación valenciana, cuelgue el retrato de Ruiz Zorrilla —entonces ministro de Justicia— en el salón de juntas ${ }^{57}$.

Consignas, himnos y cánticos no fueron los únicos sonidos que interrumpieron la rutinaria normalidad e invadieron las calles aquellos dias. Como parte inolvidable de aquellos hechos, debe considerarse el propio ruido ensordecedor que deliberadamente acompañó muchas de estas escenografias. Ilustrativo resulta, en este sentido, el caso de Oviedo. El relato de Palacio Valdés evoca muy bien ese impacto sonoro del primer acto de la revolución en una capital de provincias: cohetes, gritos de consignas, "por todas partes gran movimiento y regocijo", con el broche, muy importante, del estruendo que generaba un busto de bronce arrastrado por las calles empedradas. En este caso, también fue un "vecino progresista" quien, tras un "discurso fogoso" desde el balcón del Ayuntamiento, "arrojó a la plaza el retrato de la reina, que se hallaba en el salón de sesiones, y la muchedumbre se apresuró a hacerlo trizas rugiendo de gozo", mientras proferian un clamor que emocionó al joven Palacio Valdés:

"«Abajo las testas coronadas!". Por primera vez escuché entonces este grito eufónico, que me hizo cosquillas de placer. Si hubiera sido "iAbajo las cabezas coronadas!", no me habría producido efecto alguno. Mas la palabra testa le daba tal realce, lo hacía tan melodioso y halagüeño al oído que, si yo fuese rey, pienso que al oírme llamar testa coronada me hubiera despojado, sin inconveniente, de la corona"58.

Sin embargo, lo que ocurrió a continuación, que el novelista juzga como "graves sucesos", no fue de su agrado incluso tratándose de un republicano que lógicamente simpatizaba con La Gloriosa:

"Pero la muchedumbre allí congregada sentía necesidad para saciar sus furores, de algo más plástico que la pintura.

¡A la Universidad! ¡A la Universidad!

55 José Antonio Piqueras, La Revolución Democrática (1868-1874). Cuestión social, colonialismo y grupos de presión, Ministerio de Trabajo y Seguridad Social, Madrid, 1992, p. 42.

56 Sergio Sánchez Collantes, "La construcción simbólica del republicanismo español en el Sexenio Democrático", op. cit., p. 146. Un balance reciente de aquellos himnos, en Marie-Angèle Orobon, "La carne de la política: ruptura democrática y simbología", Ayer, no 112, 2018, pp. 7678.

57 Eduardo Higueras Castañeda, Con los Borbones, jamás. Biografía de Manuel Ruiz Zorrilla (1833-1895), Marcial Pons, Madrid, 2016, p. 162.

58 Armando Palacio Valdés, La novela de un novelista, op. cit., p. 212. 
Seguí el tropel hasta la Universidad, y vi cómo derrocaban el busto de bronce de la reina Isabel erigido en medio del patio.

Confieso que al escuchar el ruido siniestro que hizo cayendo sobre las losas, corrió por mi cuerpo un escalofrío. Vi después que unos pilluelos le echaron una cuerda al cuello, lo arrastraron fuera de la Universidad y lo pasearon en esta forma por las calles en medio de gruesa algazara.

No les seguí. Aquel espectáculo me causó extrema repugnancia. Si alguien lo atribuye a un espíritu estrecho y reaccionario, se equivocará. Ya he dicho que sonaba grato en mis oídos el grito de "AAbajo las testas coronadas!", y añado que la libertad, la igualdad y la fraternidad me tenian por entero subyugado, pues entonces no sabia cuántas cositas sucias se pueden esconder debajo de estas palabras tan bellas. Me repugnaba el espectáculo, sencillamente, porque encontraba poco galante arrastrar a una señora amarrada por el cuello"59.

El catedrático institucionista Adolfo Posada, también republicano, evocó igualmente los hechos en sus memorias:

" ¡Viva España con honra!", voceaba un grupo muy numeroso que se acercaba por el Fontán, mientras otros gritaban por la calle de la Magdalena: "¡Abajo los Borbones!», a la vez que arrastraban, atado con una soga de esparto por el cuello, el busto de bronce de la Reina Isabel que, según supe después, habian arrancado rabiosos de su pedestal en la Universidad, en tanto que unos cuantos estudiantes desmandados echaban al suelo una campana que decian odiosa, pendiente de unos hierros junto a la portería"60.

Y lo mismo un jovencísimo Leopoldo Alas Clarín que, con 16 años, lo usaba como recurso literario para el "Soliloquio de un neo" en su periódico manuscrito Juan Ruiz:

"Yo he visto con estos dos ojos pecadores y que se ha de tragar la tierra, arrastrar por esas calles y las otras el busto de una reina.

¡Qué ignominia!

Sería buena o mala, pero era reina"61.

Otro cronista que también evocó el episodio muchos años después suministró informaciones adicionales muy relevantes, al sugerir que el acto no fue tan espontáneo como pudiera creerse. En su versión, "los jefes" revolucionarios decidieron arrancar el bronce al recordar "las grandes amarguras escolares que habían pasado en el patio y claustros de nuestra Universidad"; y lo sacaron "por la puerta principal del edificio universitario, [...] para entregarle a dos docenas de chiquillos, bien preparados para la fiesta, para que le arrastrasen por todas las calles, plazas y plazuelas y callejones de la ciudad". De suerte que "al ruido infernal que producía el bronce en los choques contra los guijarros y

59 Armando Palacio Valdés, La novela de un novelista, op. cit., pp. 212-213.

60 Adolfo Posada, Fragmentos de mis memorias, Servicio de Publicaciones de la Universidad de Oviedo, Oviedo, 1983, p. 38.

61 Leopoldo Alas Clarín, Juan Ruiz (periódico humorístico), Sofia Martín-Gamero (ed.), EspasaCalpe, Madrid, 1985, pp. 253-254. 
adoquines, salian las gentes pacificas e imparciales, y aun contrarias a la monarquía, a los balcones de sus casas, retirándose tan pronto como veían el deplorable espectáculo que les regalaban las notabilidades revolucionarias". Mientras, "los chiquillos cuanto más corrian más y más se solazaban a la vista de los saltos y volteretas que daba el busto sobre las piedras y la desigualdad del suelo de las calles"; y "a cada salto, se producía un ¡hurra! de gritos entre los rapazuelos y los cuatro zagales, mayores de edad, que los guiaban". Según este autor, "así recorrieron la ciudad por espacio de dos a cuatro horas; finalizando esa fiesta popular por cansancio de los que la celebraban"62.

El caso de Oviedo presenta algunas particularidades. Por lo pronto, de contexto: la escena del busto — no así la del cuadro- no se inicia en la plaza principal de la ciudad ni ante una institución política, sino que se promueve en la Universidad. Pero, sobre todo, importa reparar en el componente simbólico de la puesta en escena: es lo más parecido a una decapitación figurada, que se remata con una práctica tan humillante para una monarca como era el hecho de verse ruidosamente arrastrada por el suelo, como sucedió también en Barcelona. La soga atada al cuello, además, tenía su paralelismo con un ahorcamiento. Finalmente, cabria preguntarse si entre los jóvenes o adolescentes que tomaron parte en esa "fiesta popular" se hallaban estudiantes, porque en otros casos parece ser un colectivo que se distinguió por su implicación; a decir verdad, no siempre espontánea: hay casos en los que el alumnado del instituto aportó "su alegría al entusiasmo general" pero tras haberse suspendido las clases para propiciarlo63. En sentido contrario, el joven Palacio Valdés se lamentaría: "me vi obligado a estudiar mi lección de Geometría lo mismo que si no hubiera caído la dinastía de los Borbones. Es vergonzoso decirlo; pero no puedo ocultar que esto enfrió un poco mi ardor democrático"64.

En lo que se refiere a la connotación de la soga, una lectura muy similar podría hacerse de lo sucedido con la estatua de Isabel II que había en Palma, presidiendo la que entonces se denominaba plaza de la Reina. La soberana había visitado Mallorca en 1860 y entonces colocó la primera piedra de un monumento que se terminó en 1863. Ejecutada en mármol por el escultor valenciano José Bover, la estatua medía 2 metros con 70 centímetros, que sumados al pedestal daban un total de 8 metros de altura. El 1 de octubre de 1868, se le ató una gruesa cuerda y fue aparatosamente derribada, momento que inmortaliza una fotografia ${ }^{65}$. La operación resultaba más impactante si cabe en un conjunto de tales características, que aumentaba la espectacularidad y reforzaba su lectura simbólica: la caída de la escultura era también la de la propia Monarquía, que metafóricamente sucumbía por la acción del pueblo. La similitud con lo sucedido en Oviedo se aprecia en las impresiones de Bartolomé Pasqual:

"Inmediatamente de recibida la noticia del pronunciamiento de Barcelona, corrieron a apedrear el monumento de la Reina, ensuciándolo todo y mutilándolo atrozmente,

62 "Recuerdos locales", El Correo de Asturias, Oviedo, 7 y 9-III-1895.

63 Alfons Romero i Dalmau, El republicanisme federal empordanès (1868-1869), Editora Empordanesa, Figueres, 1980, p. 37.

64 Armando Palacio Valdés, La novela de un novelista, op. cit., p. 213.

65 Joan Riera, "Isabel II, cinco años en el pedestal", Diario de Mallorca, 5-X-2012. Estos hechos también han inspirado una propuesta didáctica para $2^{\circ}$ de Bachillerato: véase Martí Canyelles, “Comentari d'una imatge”, Revista Cantabou, CEP de Inca, n 30, 2009, pp. 17-19. 
rompiendo estatuas y esculturas. A las diez de la noche, después de pasada un poco la tormenta, fui a ver el destrozo, y me contristé sobremanera. Vi la Reina sin corona, cetro, nariz ni manos, la cara tiznada, una cuerda atada al cuello y una porción de chiquillos y bargantells, que tiraban de la cuerda, para derribarla: [...] te aseguro que una lágrima de compasión asomó a mis ojos. Al día siguiente los chiquillos lograron arrancar la cabeza de la Reina y la pasearon arrastrando por todo Palma; mira si eran niños, que los más al arrastrarla, gritaban ¡viva la Reina!"66.

\section{Figura 5.- Un grupo "derroca" la estatua de Isabel II con una soga en Palma de Mallorca}

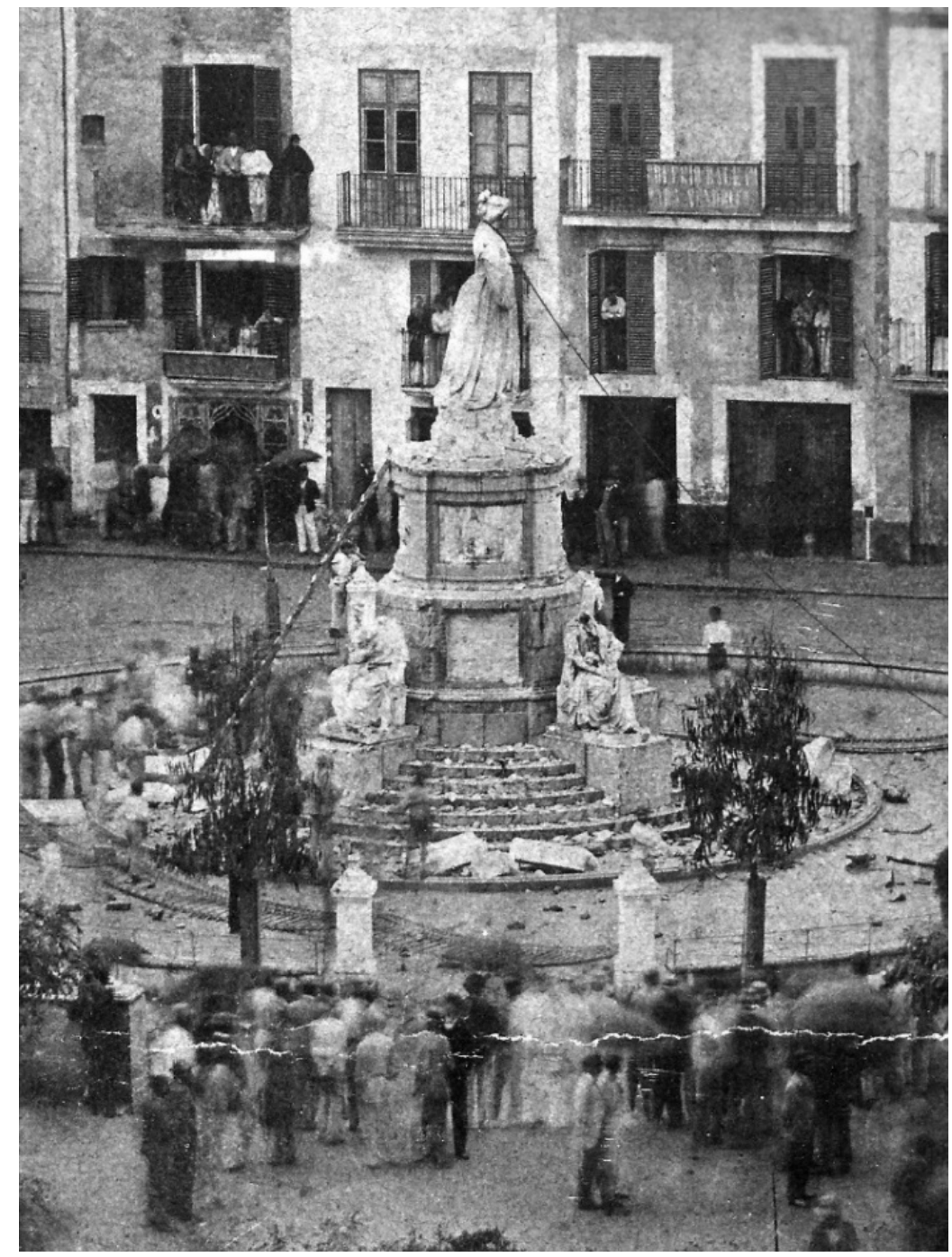

Fuente: fotografia conservada en el Arxiu Municipal de Palma y reproducida en Catalina Martorell, "150 anys de la Revolució de Setembre a Mallorca: Les classes populars passen a l'acció", disponible en https://www.aguait.cat/profunditat/150-anys-de-la-revolucio-de-setembre-amallorca-les-classes-populars-passen-a-laccio/ [con acceso el 15-IV-2019] Doy las gracias a la autora por responder a mis consultas.

66 Citado en Andreu Bestard Mas, "Anecdotario y textos críticos del autor de la "Miscelánea Pasqual"”, Bolletí de la Societat Arqueològica Lul-liana. Revista d'estudis històrics, n 39, fasc. 836, 1982, p. 218. 
Tan impresionante operación se acompañó en la ciudad y en la isla de otras actuaciones dirigidas contra los cuadros de Isabel II, no sólo de los ayuntamientos sino también de las escuelas, cuyos retratos fueron pasto de las llamas ${ }^{67}$. La prensa local también se hizo eco de algunos de estos episodios. Comunicaba que, al saberse que muchas poblaciones se habian adherido al movimiento iniciado en Cádiz, el día 1 de octubre se reunieron varios grupos que, gritando ¡Viva la Libertad! ¡Viva Prim! y ¡Abajo los Borbones!, se dirigieron a la casa del alcalde, donde "se apoderaron de varios muebles y de un carruaje, que fueron quemados en medio de gritos en la plaza de Cort". Después, hicieron lo propio en la casa del visitador de consumos y de seguido se produjo el episodio de la estatua:

"Al anochecer, los grupos se dirigieron al paseo del Borne, donde trataron de destruir el monumento dedicado por la provincia a la que acababa de ser Reina de España, doña Isabel II. Después de haber mutilado aquella obra artística, se dirigieron contra las oficinas de la administración de Hacienda, situadas en el mismo paseo, en las cuales penetraron, y mesas, taquillas, armarios, sillones y demás muebles se lanzaron por los balcones a la calle, y con ellos se encendieron dos hogueras cuyas llamas consumieron en pocas horas todos los libros y cuentas de aquella importante oficina.

Las consecuencias del desahogo popular también se dejaron sentir en las casas de algunos agentes de policía, siendo asaltadas y quemados algunos de sus muebles; pero afortunadamente sin que hubiese efusión de sangre"68.

El espacio público palmesano sufrió un proceso de resignificación que no se limitó a ese derribo ni al renombramiento de la plaza de la Reina como plaza de la Libertad, operaciones ambas que en cierto modo la desborbonizaban, sino que se completó con otras actuaciones: al fin y al cabo, toda iconoclasia venía a completarse con cierta iconofilia. Así, las autoridades municipales también acordaron plantar un emblemático árbol de la libertad justamente en el mismo sitio que había ocupado el monumento69.

Decisión muy simbólica fue, asimismo, la que adoptó el consistorio hispalense en señal de repudio hacia dos obsequios que Isabel II le había entregado a Sevilla en 1843, como premio por resistir el asedio de las tropas esparteristas: el título de invicta y la carta de bendición de una corona de oro. Pues bien, tras La Gloriosa, los munícipes ordenaron quemar el primero y fundir la segunda junto a las medallas que venian usando los concejales de la anterior

67 María Catalina Martorell Fullana, El republicanisme federal i la cultura liberal democrática a Mallorca (1840-1900), Tesis doctoral, Universitat Autònoma de Barcelona, 2015, p. 98.

68 Diario de Palma, citado en La Esperanza, Madrid, 7-X-1868, y El Pensamiento Español, Madrid, 8-X-1868. Nótese la referencia al valor artístico de las obras, que en muchos casos ha sido el aspecto más tratado por los estudiosos, pese a lo subjetivo que a veces puede resultar la consideración de lo que es o no una obra de arte, como se recuerda en Olivier Christin, Une révolution symbolique, op. cit., p. 9.

69 Isabel Peñarrubia i Marquès, "El Sexenni Democràtic (1868-1874)", en David Ginard (dir.), Quaderns d'història contemporània de Les Balears, Edicions Documenta Balear, Palma, 2005, p. 12 
situación ${ }^{70}$. La medida refleja bien la voluntad de ruptura de las nuevas autoridades, pero también la necesidad de ampararse en nuevas legitimidades.

\section{Figura 6.- Aspecto de la plaza de la Reina, en Palma, una vez abatida la estatua de Isabel II y rebautizada como plaza de la Libertad}

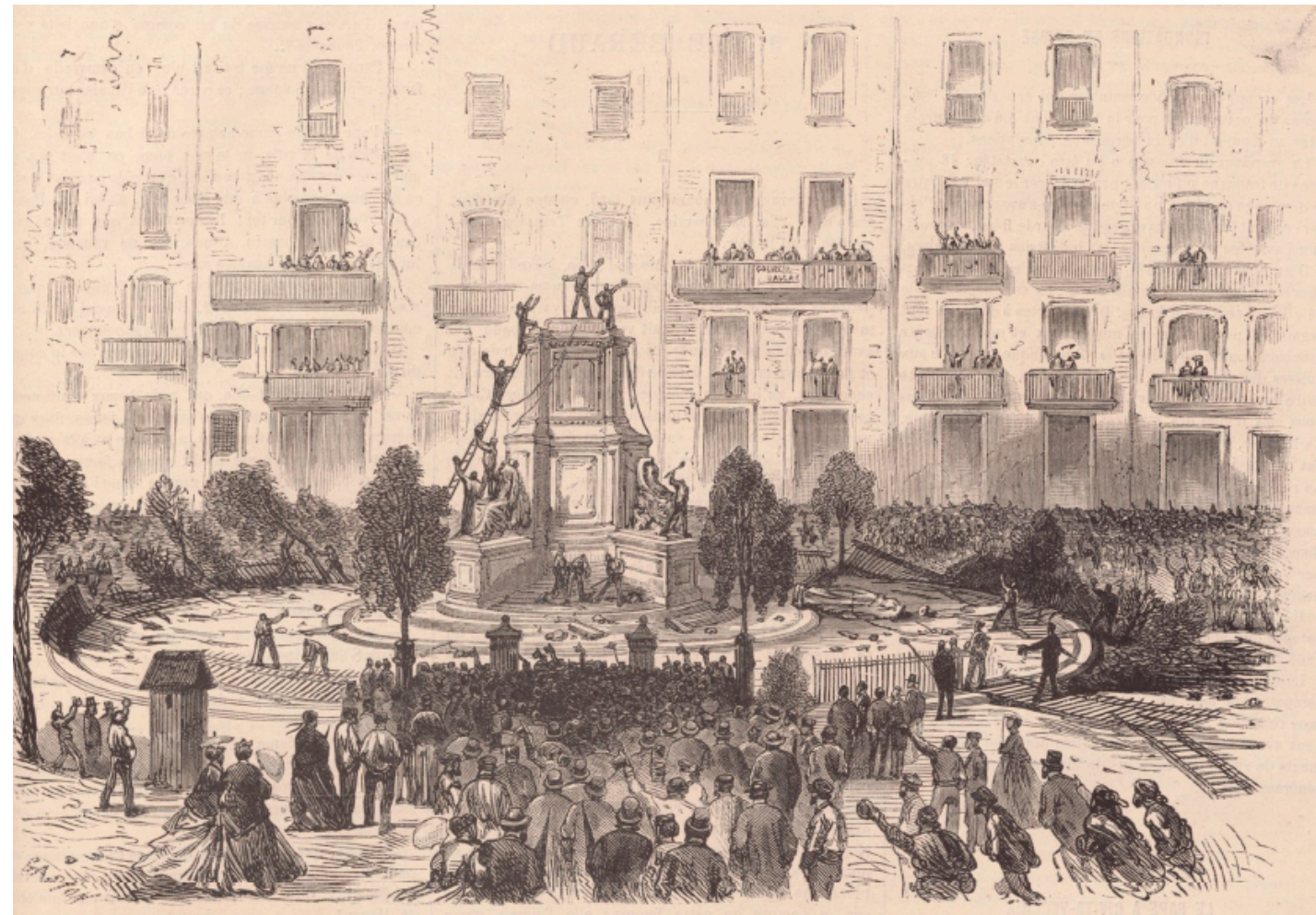

Fuente: Le Monde Illustré, Paris, 7-XI-1868 (a partir de croquis de Tomás Padró).

En fin, nada sería más fácil que seguir añadiendo testimonios para ilustrar la iconoclasia vivida en diferentes ciudades, pero hemos visto que, en general, reiteran un patrón muy similar. En Mahón, recordaban meses después: "aquí como en todas partes el pueblo se entretuvo en leer y publicar proclamas, en romper y quemar los retratos de Isabel, en dar vivas por las calles, oír tocar el Himno de Riego y destruir los rótulos de consumos, las coronas y las lápidas de las calles y de los monumentos que significaban poder real o dinastía borbónica"71. En Elche se destrozó asimismo un retrato de la soberana durante una refriega en medio de vivas a la libertad y a la revolución ${ }^{72}$. Incluso en zonas rurales o de predominio agrario se documentan esos episodios de iconoclasia

70 Eloy Arias Castañón, "La Revolución de 1868 en Sevilla: elites democráticas y masas republicanas", en Diego Caro Cancela (ed.), La Revolución de 1868 en Andalucía, Ediciones Presea, Madrid, 2018, pp. 373-374.

71 El Menorquín, Mahón, 14-VIII-1869.

72 Rosana Gutiérrez Lloret, La República y el Orden. Burguesía y republicanismo en Alicante (1868-1893), Tesis Doctoral, Universidad de Alicante, 1987, p. 192. 
politica, como en Guadalajara, donde ya se vio que el retrato de la soberana también "fue públicamente destruido y vilipendiado"73.

Recordemos que, con el precedente de ciertas provincias en las que se adelantó el estallido revolucionario, la iconoclasia antiborbónica se concentró particularmente en los días 29 y 30 de septiembre, una vez conocida la derrota de las tropas isabelinas en Alcolea ${ }^{74}$. Cabria añadir que lo mismo habría pasado en Ultramar con los preceptivos retratos de los centros oficiales y las escuelas, lugares en los que cumplian una función esencial:

"Toda escuela municipal debe tener un buen retrato de gran tamaño de S. M. nuestra augusta soberana $\mathrm{D}^{\mathrm{a}}$ Isabel II; no sólo para que los niños desde su más tierna edad graben en su imaginación la dulce fisonomía de la que es madre, y madre cariñosa del pueblo cubano, a quien mira y distingue con particular predilección, sino para rendir un ostensible homenaje de respeto a su autoridad"75.

Finalmente, deben hacerse unas consideraciones espaciales sobre la reproducción de este fenómeno en distintos lugares e incluso fuera del país. Por ejemplo, en ese contexto de fogosa supresión de emblemas isabelinos, el temor a la iconoclasia antiborbónica se notó hasta en la embajada de España en Londres, donde se quitó un retrato de cuerpo entero de la reina y fue transportado a la embajada de Portugal por considerar "que el cuadro no estaba en seguridad", ya que "podia llegar de un momento a otro un agente revolucionario"76. En cuanto a las ciudades, tampoco hay que olvidar que los hechos se desarrollaban paralelamente en muchos lugares y no sólo en las plazas principales. Incluso en las zonas céntricas podian convivir varios focos, como parece que sucedió en Madrid ("en varias calles se incendiaron fogatas donde se quemó la corona real") 77 y también en Barcelona, según refleja el testimonio de los eclesiásticos Gatell y Vilarrasa:

"La plaza Nueva, la plaza Real, la de la Constitución, el llano de la Boquería, no hubo punto céntrico algo importante que no tuviera su fogata. Y alli llovian cuadros, papeles, y para que el fuego tuviera mayores proporciones, se echaban además sillones, doseles, todo cuanto pudiera oler a monarquía"78.

Pero los desórdenes también se dieron en otros barrios alejados del centro histórico de las ciudades. Gutiérrez Gamero recuerda que "en los barrios bajos [...] se armó una regular cuchipanda con acompañamiento de vidas y mueras,

${ }^{73}$ Rafael Villena Espinosa, "La revolución tranquila: el despliegue de la Gloriosa en la España interior", op. cit., p. 61.

74 Alberto Gil Novales, La Revolución de 1868 en el Alto Aragón, Guara Editorial, Zaragoza, 1980, p. 86.

75 Mariano Dumás Chacel, Guía del profesorado cubano para 1868. Anuario de pedagogía y estadística de la Enseñanza, Imprenta El Ferrocarril, Matanzas, 1868, p. 50. La difusión de esa idea de la reina como "madre de la Nación" se combinó con la del estereotipo de "ángel del hogar" en Palacio, como han estudiado Rosana Gutiérrez Lloret y Alicia Mira Abad, "Ser reinas en la España Constitucional. Isabel II y Maria Victoria de Saboya: legitimación y deslegitimación simbólica de la monarquía nacional, Historia y politica. Ideas, procesos y movimientos sociales, $\mathrm{n}^{\circ}$ 31, 2014, pp. 139-166.

${ }^{76}$ La Correspondencia de España, Madrid, 29-X-1868.

77 M. M. de Lara, El cronista de la revolución española de 1868, op. cit., p. 118.

78 Citado en Santi Vila i Vicente, "Félix Sardà y Salvany, paradigma de una Iglesia reaccionaria y a un tiempo innovadora", Ayer, n 44, 2001, p. 200. 
rociado todo con peleón”, y ante ese panorama exclamaba: “¡Los pueblos ¡Vaya usted a quitarles su delirio del momento y expóngase a que le arrastren!"79. En suma, hay que insistir en que no todo sucedió en la plaza mayor de las ciudades, por más que ese lugar resultase neurálgico. Lo plasma bien la evocación del federal Enrique Rodríguez Solís, tras retirarse del centro de Madrid:

"Según avanzaba a mis barrios, la animación crecía; el gentío era inmenso, el bullicio colosal, el entusiasmo imponderable.

La plaza de Lavapiés, vista desde la calle del Ave María, era una segunda Puerta del Sol"80.

En todo lo ocurrido, como se ha visto aqui, desempeñaron un papel esencial los republicanos y los progresistas. Es verdad que los primeros tuvieron un protagonismo notable, y que incluso hicieron una lectura de los destrozos genéricamente antimonárquica, no sólo antiborbónica, tratando de instrumentalizar y vehicular esa furia popular al frente de las operaciones en numerosas ciudades. Pero no hay que ignorar que los progresistas también figuraron a menudo en primer plano y que en muchos lugares desempeñaron un liderazgo inequívoco, como prueban las actuaciones de Valencia o Valladolid. No faltan autores que hayan considerado que esa conducta tan señalada en algunas destrucciones y ciertos gestos posiblemente tuvieron resultados contraproducentes para los progresistas, por alentar "actitudes genéricas antimonárquicas"81.

\section{OTRAS EXPRESIONES DEL REPUDIO}

Las manifestaciones antiborbónicas fueron más allá de los bustos y los retratos, circunstancia que amplía su alcance y significación. Ya se han adelantado varios ejemplos en testimonios citados, pero hubo más. Por lo pronto, el repudio se expresó también en el nomenclátor callejero, como es bien sabido, por decisión tanto de las juntas revolucionarias como de las autoridades que les sucedieron. Ya se indicó el caso de la plaza de Palma. En Barcelona -entre otras mudanzas - se rebautizó la plaza Real como plaza Nacional, se destruyó el pedestal que en su centro debía sostener la estatua de Fernando VII y desapareció la calle que llevaba el nombre de este rey ${ }^{82}$. En Madrid, a su vez, entre otros muchos cambios, la plaza de Isabel II recibió el nombre de Prim (una modificación que se recordaría medio siglo después) ${ }^{83}$. Menos conocido es, pero muy significativo, el cambio de la denominación de municipios enteros, como el de Nava del Rey, pequeña localidad del suroeste de la provincia de Valladolid, que en estos momentos decidió llamarse Nava de la Libertad, conservando este

79 Emilio Gutiérrez Gamero, Mis primeros ochenta años, I, op. cit., p. 235.

80 Enrique Rodríguez Solís, Memorias, op. cit., p. 99

81 José Antonio Piqueras, La Revolución Democrática (1868-1874), op. cit., pp. 42-43. Sobre lo ocurrido en el palacio del Temple de Valencia, añade: "La ebriedad del halago probablemente ha llevado a Peris y Valero más lejos de lo deseado".

82 Conrado Roure, Recuerdos de mi larga vida, III, op. cit., p. 103-104.

83 El Imparcial, Madrid, 2-X-1928 (se dedica una plana a la efeméride del triunfo de La Gloriosa). 
nombre hasta $1874^{84}$. Y tampoco hay que subestimar el impacto de otros letreros más efimeros fruto de la espontaneidad del momento; o de grafitis como el que apareció en grandes caracteres en la pared del Ministerio de Hacienda, de autor anónimo: "Cayó para siempre la raza espuria de los borbones"85.

\section{Figura 7.- Viñeta de un aleluya relativa al grafiti contra los Borbones aparecido en} 1868

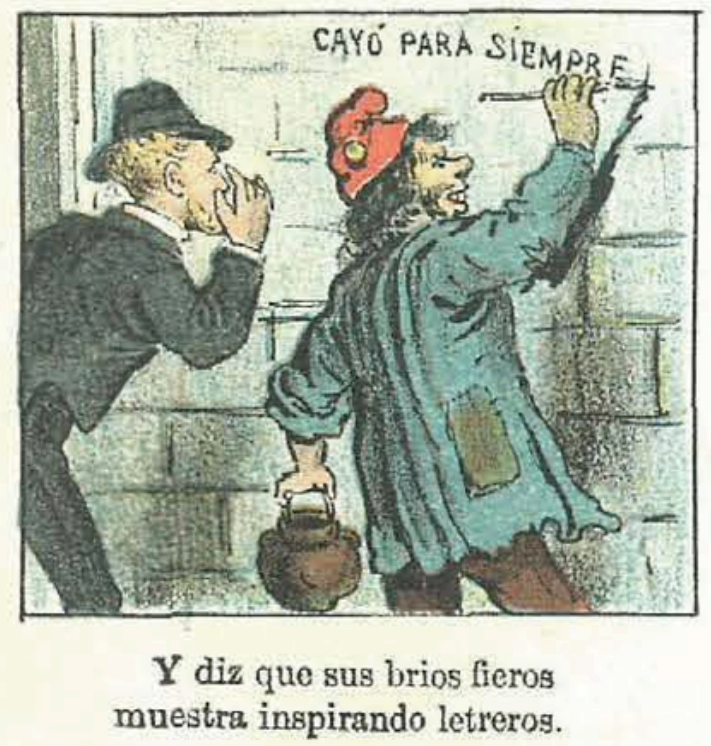

Fuente: El Motín, Madrid, 28-VIII-1881. Romero Robledo es quien aparece "inspirando" al autor.

Otra transformación relevante es la que se aplicó en el exterior del Congreso, donde se enarboló una bandera de la que se había arrancado el escudo real ${ }^{86}$. De hecho, parece que esto ocurrió en otros edificios oficiales y cuarteles en los que el pabellón ondeó "con un agujero en el centro"87. También hemos adelantado que hasta los propios soldados y oficiales, mientras "fraternizaban con las masas populares", llegaron al extremo de arrancarse de sus roses y uniformes las coronas e iniciales que lucian en las hombreras y chapas, empezando por el general Ros de Olano, que lo hizo "a la vista del numeroso público que llenaba la Puerta del Sol"88. Más allá de los relatos de la prensa o los cronistas, un gesto tan llamativo tenía que reflejarse en la correspondencia particular de quienes relataron los hechos, y hay una carta del Fondo de Posada Herrera que describe la escena: "ellos mismos han arrancado por sus propias manos las hombreras de su uniforme (con buen trozo de paño) por contener la corona e iniciales de I[sabel]

84 Federico Carbonero, Historia de la Nava del Rey, op. cit., p. 48.

85 Emilio Gutiérrez Gamero, Mis primeros ochenta años, I, op. cit., p. 234. Se le atribuía "su paternidad" a Romero Robledo, según recuerda Manuel Espadas Burgos, Alfonso XII y los origenes de la Restauración, CSIC, Madrid, 1990, p. 372.

86 M. M. de Lara, El cronista de la revolución española de 1868, op. cit., p. 118.

87 Antonio Altadill, La Monarquía sin monarca. Grandezas y miserias de la Revolución de Septiembre, Eduardo González Editor, Barcelona, 1869, p. 10.

88 La Correspondencia de España, Madrid, 30-IX-1868. 
$2^{\text {a" } 89}$. Asimismo, el regimiento que se llamaba de Isabel II, mandado por el coronel José Chinchilla, pasó a denominarse regimiento de La Libertad ${ }^{90}$. Hasta en la audiencia territorial, al poco de triunfar la revolución, se celebró una reunión en la que decidieron quitar el retrato de Isabel II y administrar justicia "en nombre de la nación" 91 . Por no hablar de otros ámbitos como el universitario, en el que sería interesante profundizar: el retrato de la monarca en el estrado del paraninfo de la Universidad Central fue reemplazado por las leyendas "Libertad de Ciencia" y "Veritas Liberabit Vos"92.

Escenas parecidas se reprodujeron en diferentes provincias. Como ha estudiado Martínez López, en Almería "fueron borrados [...] todos los símbolos contrarios a la Revolución", incluyendo la corona y las iniciales de Isabel II que lucían en los escudos usados por "los cuerpos del ejército y clases de estado" 93 . En Valladolid también fueron rotas las efigies de la reina que lucían en los estancos, acción que, por otro lado, no puede desvincularse de una de las reivindicaciones planteadas desde las juntas revolucionarias: el desestanco de la sal y el tabaco ${ }^{94}$. La junta de Cádiz, por su parte, incluso acordó mandar un oficio al arzobispo para que en las preces eclesiásticas desapareciera el nombre de Isabel II ${ }^{95}$.

Entretanto, la Gaceta de Madrid apareció el 30 de septiembre, en lugar de con el escudo de armas borbónico, con una alegoría femenina que, acompañada de un león y un gallo, sostiene una balanza de la justicia, lo que representa, como gráficamente ha explicado Orobon, "a la nación dueña de sus destinos y no ya de una dinastía"96. A la postre, serán de gran relevancia todos los cambios que experimentó el escudo nacional al suprimirse las borbónicas flores de lis y la corona real — sustituida por la mural-, modificaciones todas ellas que se proyectaron en banderas, monedas, timbres y mobiliario oficial ${ }^{97}$.

89 Archivo Histórico de Asturias, Fondo Posada Herrera,11.408/37 (carta de Joaquín a su padre fechada en Madrid el 29-IX-1868).

90 La Época, Madrid, 1-X-1868.

91 El Imparcial, Madrid, 1-X-1868.

92 Antonio Jiménez-Landi, La Institución Libre de Enseñanza y su ambiente. I. Los orígenes de la Institución, Editorial Complutense, Madrid, 1996, p. 191.

93 Fernando Martínez López, Los republicanos en la política almeriense del siglo XIX, Fundación Unicaja, Málaga, 2006, 61-62.

94 Rafael Serrano García, El Sexenio Revolucionario en Valladolid. Cuestiones sociales (18681874), Junta de Castilla y León, Valladolid, 1986, p. 64.

95 El Imparcial, Madrid, 1-X-1868.

96 Marie-Angèle Orobon, "El cuerpo de la nación: alegorias y símbolos políticos en la España liberal (1808-1874)", Feminismo/s, no 16, 2010, p. 56.

97 Luis Castro Berrojo, Héroes y caídos. Politicas de la memoria en la España contemporánea, Catarata, Madrid, 2008, p. 56. 
Figura 8.- Las armas borbónicas desaparecen de la Gaceta

\begin{tabular}{|c|c|c|}
\hline 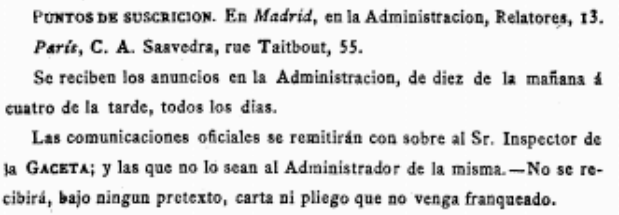 & 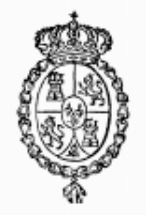 & $\begin{array}{l}\text { Precios de suscriciox. En Madrid, por un mes, } 1 \text { escudo } 200 \text { mile- } \\
\text { simas. - Por tres meses, } 3 \text { escudos } 600 \text { milesimas. } \\
\text { Provincias, inclusas Islas Baleares y Cantarias, por tres mesee, } 6 \text { oscu- } \\
\text { dos. - Por seis meses, } 12 \text { escudos. - Por un afio, } 22 \text { ebcudos. } \\
\text { Ultramar, por tres meses, } 9 \text { escudos. } \\
\text { Extranjero, por tres meses, } 7 \text { escudos } 200 \text { milesimas. - Por seis meses } \\
14 \text { escudos } 400 \text { milceimes. }\end{array}$ \\
\hline 1 & & \\
\hline
\end{tabular}

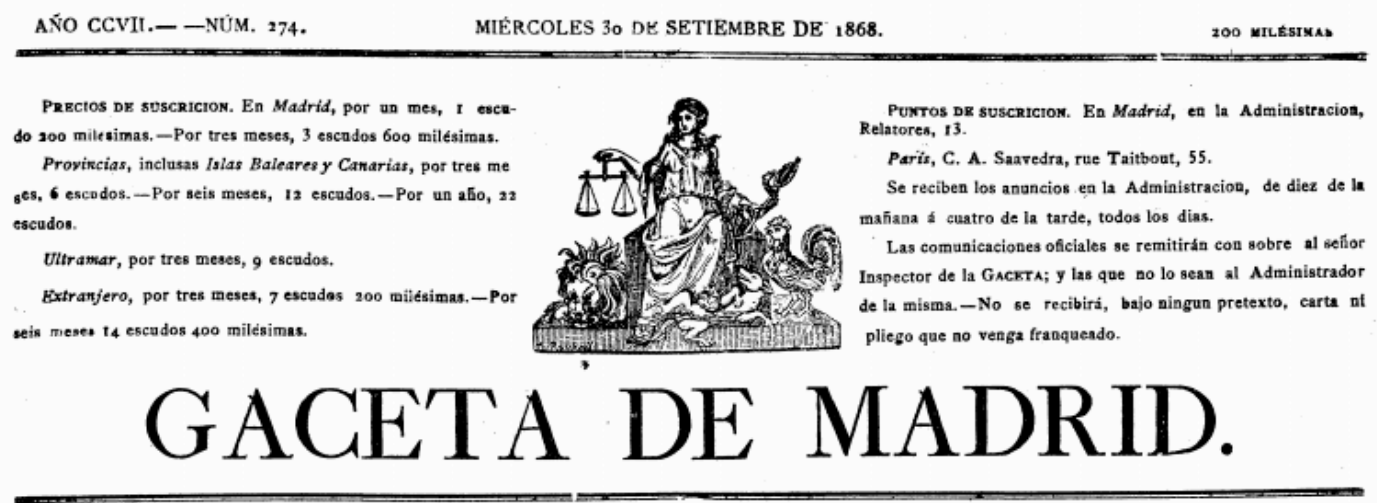

Fuente: Gaceta de Madrid, 29 y 30-IX-1868, disponible en la colección histórica de la Gaceta, en https://www.boe.es/buscar/gazeta.php [con acceso el 12-IV-2019]

Las monedas, por su parte, merecen una consideración específica. La execrada imagen de la reina desapareció también de este soporte y la flamante peseta, entonces aprobada por el Gobierno provisional, exhibió una serena alegoría de Hispania reclinada sobre unas montañas que representaban los Pirineos. De semejante transformación numismática, que borró a Isabel II de toda moneda, se hizo eco — con ilustraciones incluidas - hasta la prensa extranjera ${ }^{98}$. No deja de ser reveladora una caricatura de 1875 que, a modo de eje cronológico, hace un balance de las etapas vividas desde 1868, porque quien ejecutó el dibujo consideró significativo plasmar cómo se fueron proyectando en las monedas ${ }^{99}$.

98 "Nouvelles monnaies Espagnoles", Le Monde Illustré, Paris, 6-III-1869.

${ }_{99}$ La Madeja, Barcelona, 14-III-75. 
Figura 9.- Evolución de las monedas en una caricatura (detalle)

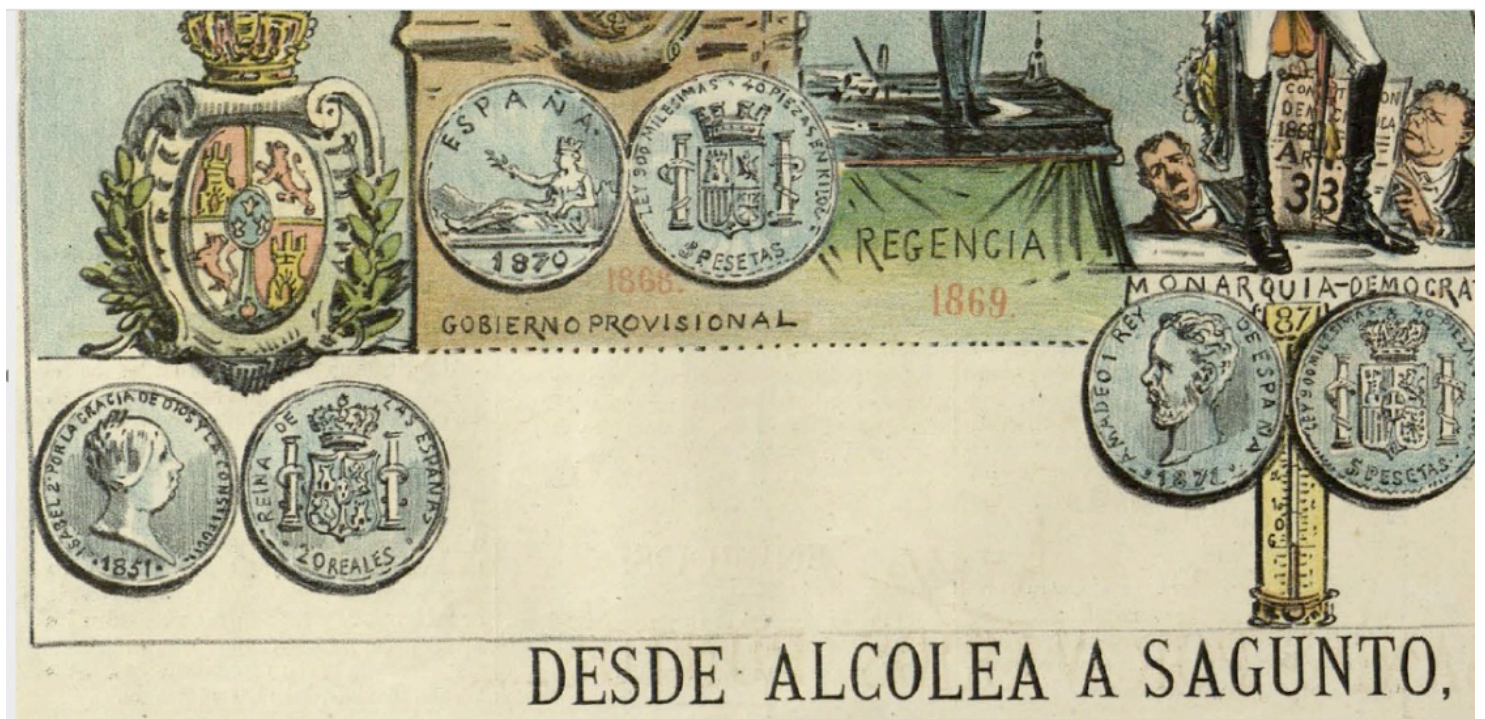

Fuente: La Madeja Política, Madrid, 14-III-1875.

No es un detalle menor que la Constitución de 1869, entre las facultades que le reservaba al monarca en su artículo 73, recogiese expresamente la de "cuidar de la acuñación de la moneda, en la que se pondrá su busto y nombre"100. Pero ya no se haria en los términos habituales. La monarquía de Amadeo I, debido a la insólita legitimidad de haber sido elegido por las Cortes, evitó la tradicional intitulación "por la gracia de Dios" o "Dei gratia", aunque sin aclarar cuál era su nueva fuente de legitimidad ${ }^{101}$. Ni que decir tiene que esto redundaba en el proceso de desacralización que la institución vivió desde que sobrevino el estallido revolucionario. La prensa satírica no dejó de ironizar sobre el cambio introducido bajo Amadeo, cuya legitimidad descansaba en el respaldo que había obtenido su candidatura en las Cortes: "por la g[racia] de 191 [votos]", decía una caricatura republicana en la que figuraba como Macarroni I.

100 Constitución de 1869 y leyes orgánicas, municipal, provincial, electoral y de orden público, Imprenta de E1 Puente de Alcolea, Madrid, 1870, p. 30.

101 Y eso que podría haber figurado como "Rey constitucional de España" en lugar de "Rey de España" a secas, como apunta José María de Francisco Olmos, "La Peseta: nueva unidad monetaria y medio de propaganda politica (1868-1936)", en Maria del Mar Royo Martínez y otros (eds.), VII Jornadas sobre Documentación Contemporánea (1868-2008), Departamento de Ciencias y Técnicas Historiográficas de la Universidad Complutense, Madrid, 2008, pp. 144-145. 


\section{Figura 10.- Sátira sobre la legitimidad de Amadeo I en las monedas (detalle de viñeta republicana)}

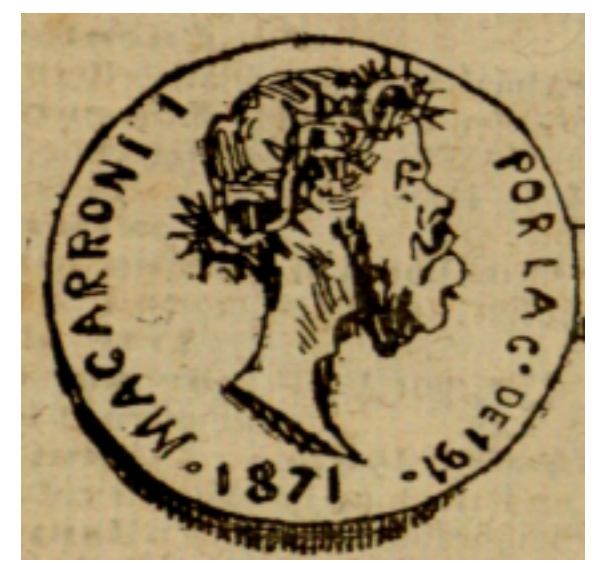

Fuente: Lo Xanguet. Almanach per l'any 1872, I. López Editor, Barcelona, 1871.

Muchos ámbitos y espacios de la vida cotidiana, en fin, padecieron igualmente los efectos de esta iconoclasia desborbonizadora. Gutiérrez Gamero recordaba cómo fueron también suprimidas "las reales coronas en las tiendas que ostentaban este emblema monárquico"102. Un punto que también ilustra la documentación privada, como se lee en una de las cartas del Fondo de Posada Herrera: "han sido rotas y arrojadas al arroyo cuantas armas reales estaban colocadas sobre las tiendas de la Puerta del Sol"103. Otro documento del mismo archivo asegura que, ante las iniciales S[u] M[ajestad], "se precipitan a tirar abajo los rótulos los mismos dueños"104. Y muy elocuente resulta, por otro lado, el cambio que padeció en Madrid el café de la Princesa, que mudó toscamente su nombre para homenajear a un adalid de la Septembrina, el marqués de los Castillejos, pero de una forma un tanto ordinaria: se quitaron las dos últimas sílabas para rebautizarlo, "con mala ortografia", como el "café de Prin"105. Sea como fuere, no parece fácil deslindar las acciones que se ejercían sobre los edificios oficiales de otras operaciones, porque todo formaba parte del mismo proceso de lucha simbólica que ocurría al mismo tiempo. En Málaga, por ejemplo, un grupo se dirigió al teatro del Príncipe Alfonso y destruyó el rótulo de la fachada con el nombre del coliseo, mientras que otra cuadrilla fue al Ayuntamiento, donde arrancó "un dosel con la corona y, tras un violento discurso, lo llevó a la Plaza y lo quemó entre vivas y mueras"106.

Hay, por lo demás, un aspecto que no hay que soslayar por el interés que sin duda encierra para la historia de las emociones: el fuerte componente

102 Emilio Gutiérrez Gamero, Mis primeros ochenta años, I, op. cit., p. 234.

103 Archivo Histórico de Asturias, Fondo Posada Herrera,11.408/37 (carta de Joaquín a su padre fechada en Madrid el 29-IX-1868).

104 Archivo Histórico de Asturias, Fondo Posada Herrera,11.408/37 (pasquín con texto manuscrito dirigido a Posada Herrera, sin firma ni fecha [sin duda 29 o 30-IX-1868).

105 La Iberia y La Correspondencia de España, Madrid, 30-IX-1868.

106 Manuel Morales Muñoz, El republicanismo malagueño en el siglo XIX. Propaganda doctrinal, prácticas politicas y formas de sociabilidad, Málaga, Asukaria Mediterránea, 1999, p. 56; referencia gracias a la cual pudimos localizar y conocer los datos adicionales recogidos en Narciso Diaz de Escovar, De la vieja Málaga, s.e,, s. 1., s. p. 
sentimental de casi todas las escenificaciones mencionadas, que además se refleja bien en los adjetivos utilizados por los cronistas ("entusiastas" vivas y mueras; masas que, "rugiendo de gozo", hacen trizas un cuadro, etc.). Mientras el desahogo se canalizase de esta forma, nada habia que temer, como demuestra la activa participación de dirigentes progresistas, que en las intentonas que habian proyectado a mediados de los sesenta temieron "un desbordamiento popular que entorpeciera sus objetivos de cambio político limitado y controlado"107. Eran, pues, excesos en el fondo inocuos, por más que al correr de los años hubiera en Asturias quien tratase de buscar antecedentes a la Revolución de 1934 en aquel "juego de chicos" de 1868 en el que "la euforia republicana se solazara arrastrando por el ámbito universitario el busto de la Reina Isabel II"108. Siempre resultaría más fácil concederle eso a las masas que otras exigencias socioeconómicas de calado.

En relación con lo emocional, además, hay que tener en cuenta que el propio material de los bustos terminaba imprimiendo al acto su dosis de gesticulación y patetismo: no era nada fácil acabar con ellos. El testimonio del pintor francés Regnault es muy elocuente en el pasaje que describe a los madrileños destruyendo "con rabia, a martillazos", todos los símbolos recordatorios de los Borbones ${ }^{109}$. Porque resultaría dificil hacerlo solamente con las manos. Y existe otra consideración que debe hacerse sobre lo que significaba destrozar un mármol: en el momento de la ejecución del busto, se había elegido por ser un material noble, que por tanto realzaba el valor y el homenaje de lo representado, lo que no dejaba de conferirle a su destrucción un mayor grado de sacrilegio o desprecio simbólico. En el mismo sentido, si analizamos los medios empleados para la destrucción de retratos o emblemas en soportes de fácil inflamabilidad, no hay que olvidar el fuerte simbolismo del fuego como elemento ritual y purificador. De suerte que las quemas se convertian en un verdadero auto de fe, y asi lo percibieron muchos contemporáneos (ya se vio que Conrado Roure o Apeles Mestres usaron dicha expresión). La combustión del trono real, por cierto, fue una imagen de lo más significativa dentro de la gama de representaciones gráficas que plasmaron los episodios de iconoclasia politica vividos en Francia desde la Revolución Francesa ${ }^{110}$.

107 Eduardo Higueras Castañeda, Con los Borbones, jamás, op. cit., p. 75.

108 Acción, Gijón, 27-X-1934.

109 Citado en Jorge Vilches, Isabel II. Imágenes de una reina, Sintesis, Madrid, 2007, p. 270.

110 Véanse las muchas láminas compiladas en Emmanuel Fureix (dir.), Iconoclasme et révolutions. De 1789 à nos jours, op. cit., a partir de la p. 160 . 


\section{Figura 10.- Destrucción de escudos borbónicos a martillazos en la obra de Altadill}

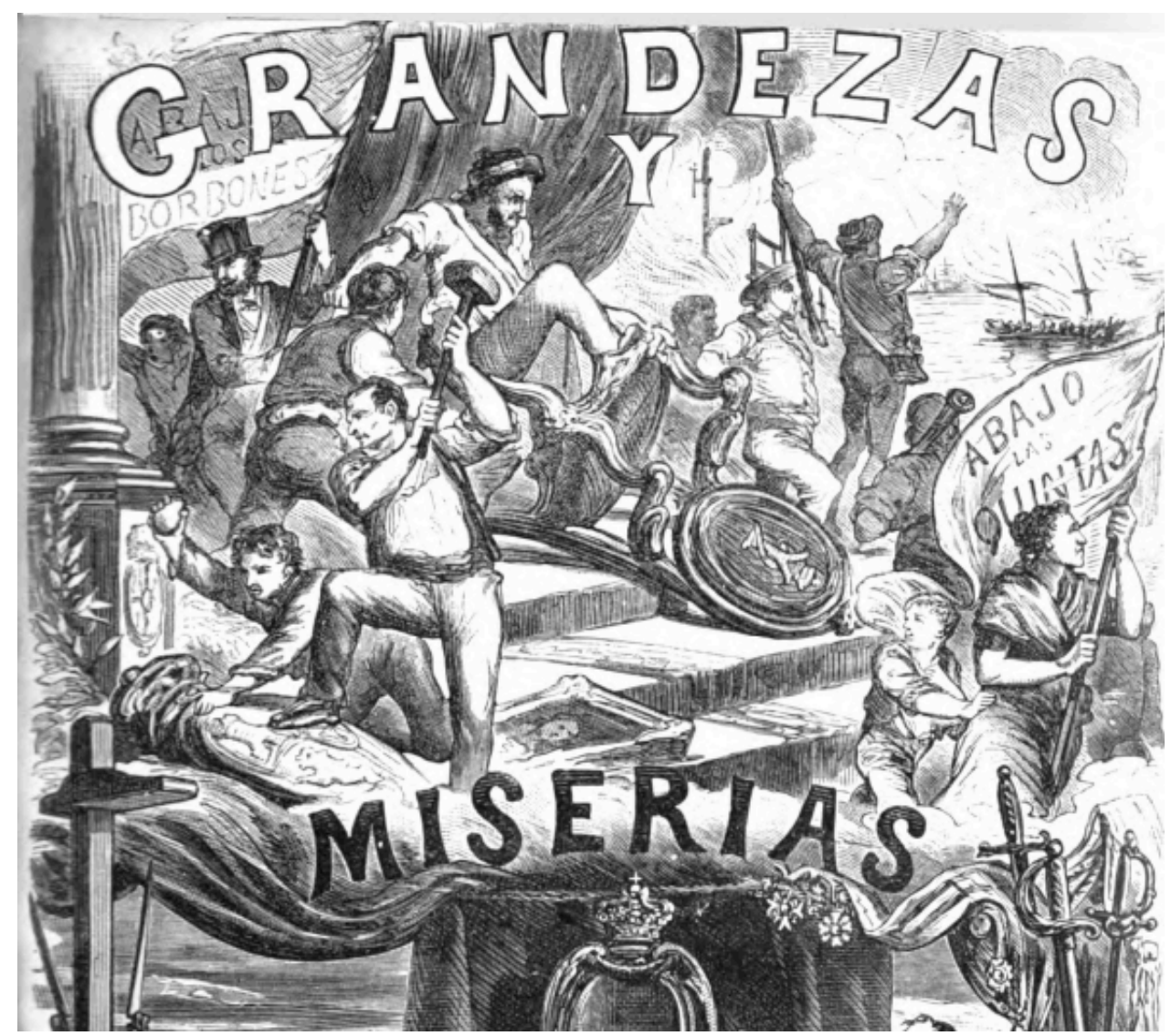

Fuente: detalle de la portada de la obra de Antonio Altadill, La Monarquía sin monarca, op. cit., 1869.

Toda revolución es bulliciosa y despierta intensos sentimientos en quienes la viven y en quienes la "padecen". Eulalia de Borbón, hermana de Alfonso XII, afirma en sus memorias: "experimenté las primeras emociones de mi vida con la revolución de 1868"111. Gutiérrez Gamero, que presenció entre la multitud las entradas de Serrano y de Prim en Madrid, recurre a sintagmas elocuentes al hablar del "júbilo delirante de los innumerables espectadores", "los gritos y el palmoteo", "los fervores de aquellos días", etc. ${ }^{112}$. Hasta alguien como Palacio Valdés, que confesó sentir repugnancia por el espectáculo del busto en Oviedo, reconocía sucumbir ante "la nostalgia del desorden" al recordar aquellos días"13. También el federal Nicolás Estévanez recuerda gráficamente, en sus memorias, las reacciones que se produjeron el 29 de septiembre a medida que se iban confirmando las noticias del triunfo de la revolución (los "vítores ardorosos", "los gritos de la multitud", el "clamor inmenso"). Ni los "más hombres" mantuvieron el tipo que requeria la masculinidad entonces normativa:

"Un anciano, que estaba en aquel momento junto a mí, se abrazó a mi cuello sollozando; al tipógrafo Vicente Álvarez, por cierto nada llorón, lo vi en aquel instante llorar como una vieja. [...]

111 Memorias de Eulalia de Borbón, op. cit., p. 11.

112 Emilio Gutiérrez Gamero, Mis primeros ochenta años, I, op. cit., pp. 240-241.

113 Armando Palacio Valdés, La novela de un novelista, op. cit., p. 217. 
Se comprende la emoción, el entusiasmo, el delirio, tratándose de un pueblo moralmente esclavizado [...]"114.

En otro orden de consideraciones, cabría situar ya no las acciones dirigidas a la destrucción física de las imágenes de la reina (bustos, retratos...), sino todos los discursos concebidos con el propósito de deslegitimarla menoscabando su reputación, algo que no dejaba de funcionar, también, como una destrucción simbólica en un siglo en que la defensa del honor provocaba desafios y duelos en toda Europa. Isabel Burdiel explica muy claramente "la degradación que había alcanzado la imagen de Isabel II", "cada vez más desquiciada y brutalizada"115. Los republicanos ya habian desempeñado un papel esencial en ese desgaste de los últimos años del régimen isabelino ${ }^{116}$. Y en los primeros días de la revolución esto se acentuó: Isabel de Borbón se presentaba como una reina ingrata, cruel, inmoral, etc. ${ }^{117}$. Y después, se multiplicaron las alusiones ultrajantes y vejatorias, incluso en las mismas crónicas que informaban de la iconoclasia que se estaba produciendo. Baste para ilustrarlo la nota que describía lo sucedido en Jerez de los Caballeros (Badajoz):

"La población en masa se dirigió a las Casas Consistoriales dando entusiastas vivas a la Libertad y a Prim; penetró en ellas, y sacando el retrato de doña Mesalina de Borbón, lo arrojó a la hoguera que había encendida en la Plaza. Después recorrió el Pueblo la ciudad, tocando varias bandas de música el popular y patriótico himno de Riego"118.

Mesalina había sido la tercera esposa del emperador Claudio y se le atribuyeron continuas infidelidades que hicieron que su nombre acabase funcionando como sinónimo de "prostituta". La velada alusión no podía pasarle inadvertida al lector cultivado, ya que los diccionarios españoles recogían esa voz con acepciones similares ${ }^{119}$. El calificativo de Mesalina aplicado a la Reina, de todas formas, no dejaba de ser un registro culto que también se populariza gracias a folletos, periódicos y otros canales.

Es interesante, en definitiva, conectar el fenómeno iconoclasta con ciertas retóricas y lenguajes, puesto que de lo que se trataba era de acabar con Isabel II y con su reputación desde cualquier punto de vista, para desacralizar completamente la monarquía y socavar la legitimidad de su dinastía en particular. Sin embargo, los republicanos iban más allá, porque consideraban

114 Nicolás Estévanez, Mis memorias, op. cit., p. 158

115 Isabel Burdiel, Isabel II. Una biografía (1830-1904), Taurus, Madrid, 2016, pp. 793 y 795.

116 Rosana Gutiérrez Lloret, "Isabel II, de símbolo de la libertad a deshonra de España", en Emilio La Parra (coord.), La imagen del poder. Reyes y regentes en la España del siglo XIX, Sintesis, Madrid, 2011, p. 255.

117 Jorge Vilches, Isabel II, op. cit., pp. 266-269

118 “Crónica revolucionaria”, La Iberia, Madrid, 7-X-1868.

119 Desde el de Covarrubias de 1611 ("Fue mala hembra y luxuriossísima, tanto que mudado el hábito por no ser conocida se yba a la casa pública") hasta los publicados en el XIX: "aristócrata ramera, tan elevada en vicios como en alcurnia" (1853); como uso metafórico, "mujer de costumbres disolutas" (1854); "mujer licenciosa, por alusión a la esposa del emperador Claudio" (1901). Véase el Nuevo Tesoro Lexicográfico de la Lengua Española de la RAE, disponible en http://ntlle.rae.es/ntlle/SrvltGUILoginNtlle [con acceso el 10-IV-2019] 
que "al destruir la dinastía de los Borbones" quedaban también inhabilitados "la monarquía, el cetro y la corona de los reyes"120. Al correr de los meses, echarán mano de representaciones ingeniosas, como las que se documentan en Béjar para replicar a las celebraciones por la promulgación del texto constitucional de 1869: lo hicieron "vistiendo a un monigote de rey con su correspondiente corona, al cual después de haberle paseado acompañándole un cortejo fúnebre, se le dio sepultura con cristiano recogimiento"121.

¿Cuánto podía durar aquel consenso simbólico que se limitaba a lo que habia que suprimir? La forma en que se escenificó la destrucción de las imágenes borbónicas y las que representaban a Isabel II encerraba dos incógnitas: por un lado, lo que se destruía y el impulso aglutinador que suscitó la caída del régimen isabelino no tenía su equivalente en lo que iba a crearse, de modo que aquel consenso efimero desembocó en la más absoluta divergencia de proyectos, expectativas y simbolos; por otro lado, la efectista movilización callejera que favoreció la iconoclasia antiborbónica daba un protagonismo a las clases populares que no tardó en percibirse como un peligro. Hubo quienes empezaron a ver en aquellas masas, no al pueblo, sino - en la terminología habitual de la época- al populacho, la chusma y las turbas desbocadas. Aunque no todos se expresasen en esos términos, en el fondo de ciertos testimonios latía ese temor al desbordamiento popular. Así ocurre en quien recelaba de "la exaltación y el desenfreno de que se hallaba poseido parte del vecindario", con ninguna simpatía hacia "los desaforados gritos de la plebe, dando vivas a la libertad y mueras a la reina" 122 .

Evidentemente, hubo en tales hechos una vertiente de "bullanga politica", dicho en palabras de Galdós, que reconoció que su familia "se asustó del barullo revolucionario" al presenciar "las demasias de la plebe barcelonesa"; pero que al mismo tiempo "era una revolución de alegria, de expansión en un pueblo culto"123. También se ha hablado de "bullanga romántica" para definir lo sucedido124. Aunque la percepción del "bullanguero" en su tiempo es eminentemente peyorativa. El médico Federico Rubio explicó que "caracterizaba a los exaltados de baja estofa, que no teniendo arraigo ni cosa que perder, gritaban y se agitaban por hábito, dando vivas y mueras en las esquinas en toda ocasión, en las plazas públicas en época de pronunciamiento"125. Durante la guerra civil, la palabra habia servido para designar "a los patriotas de café, amigos de todo lo que fuese movimiento y jarana"126. ¿En qué medida peligró de verdad la seguridad de algunas personas? En esto sí que la casuística local es amplia, porque sin duda hubo sitios en los que cierta gente tenía razones para sentir miedo. En Almería, por ejemplo, la noche del 29 de septiembre fueron asaltadas

120 La Discusión, Madrid, 27-XI-1868.

121 Antonio Altadill, La Monarquía sin monarca, op. cit., p. 495.

122 Luis Cordavias, La monja de las llagas, op. cit., pp. 116-117 y 124.

123 Benito Pérez Galdós, Recuerdos y memorias, Tebas, Madrid, 1975, p. 197.

124 Iris M. Zavala, La Revolución de 1868 (Historia, Pensamiento y Literatura), Las Américas Publishing Company, New York, 1970, p. 443.

125 Federico Rubio y Galí, Mis maestros y mi educación, Tebas, Madrid, 1977, p. 312.

126 Manuel Ruiz de Quevedo, Diccionario de politica (est. prel. de Gonzalo Capellán), Universidad de Cantabria, Santander, 2016 [1849], p. 274. 
varias casas de conocidos monárquicos por grupos que arrojaron los cuadros de Isabel II por las ventanas ${ }^{127}$. A la postre, se entró en una fase de banalización por hastío equiparable a lo que ocurria al multiplicar la difusión de la efigie real y de otros héroes nacionales o alegorias por la vía de las monedas, los billetes, los sellos, las estatuas y otros soportes que terminaban rutinizando esa imagen ${ }^{128}$.

Quizás la mayor contradicción que pudo darse aquellos dias es que hubiera quienes participasen o aplaudiesen el estallido iconoclasta sin llegar a comprender bien lo que se destruía. Parece haber sido el caso, por ejemplo, de los chiquillos que arrancaron la cabeza de la reina y la remolcaron por Palma de Mallorca: "mira si eran niños, que los más al arrastrarla, gritaban ¡viva la Reina!"129. Pero hay que admitir, incluso, la posibilidad de que mucha gente adulta no supiera quiénes eran esos Borbones contra los que se gritaba, según reflejan testimonios como el de Ramón y Cajal, referido al diminuto pueblo en que vivía [Ayerbe, en Huesca]:

"A uno de los más exaltados patriotas, ronco a fuerza de gritar: ¡Abajo los Borbones!, le preguntaron: -Pero, ¿sabes tú quiénes son los Borbones? Y el interrogado contestó con aire de profunda convicción: - ¡Otra que diez!... Pues, quiénes han de ser sino... los [guardias] rurales"130.

\section{LA MULTIFUNCIONAL ICONOCLASIA ANTIBORBÓNICA DE 1868: UN BALANCE}

El fenómeno iconoclasta desatado al calor de la revolución de 1868 — con su ola destructora de simbolos y emblemas recordatorios de Isabel II, su dinastía y, en general, la situación política anterior - no debe verse como un simple arrebato vandálico o un episodio de frivola clastomanía. Los estallidos policéntricos ocultaban muchos significados y funciones que hay tener presentes. Este artículo ha tratado de recoger las diferentes caras de tales episodios, de acuerdo con una propuesta interpretativa que se podría resumir en los siguientes puntos:

1. Representaba un destronamiento o derrocamiento simbólico (en algunos casos, con una posible lectura de decapitación o de ahorcamiento en sentido figurado) que sirvió para escenificar metafóricamente y hacer tangible a escala local el cambio de régimen, el final de una época que muchos percibian como ominosa; en suma, una especie de contrapunto de lo que sucedía por doquier a raíz de una coronación, puesto que también sirvió para legitimar a los revolucionarios en medio de la ocupación ruidosa del espacio público.

127 Fernando Martínez López, "La "Gloriosa" en Almería (1868-1870)", en Diego Caro Cancela (ed.), La Revolución de 1868 en Andalucía, op. cit., p. 173.

128 Justo Beramendi y Antonio Rivera, "La nacionalización española: cuestiones de teoría y método", en Félix Luengo Teixidor y Fernando Molina Aparicio (eds.), Los caminos de la nación. Factores de nacionalización en la España contemporánea, Comares, Granada, 2016, p. 24.

129 Citado en Andreu Bestard Mas, “Anecdotario y textos críticos del autor de la "Miscelánea Pasqual”", Bolletí de la Societat Arqueològica Lul-liana. Revista d'estudis històrics, n 39, fasc. 836, 1982 , p. 218.

130 Santiago Ramón y Cajal, Recuerdos de mi vida, op. cit., p. 98. 
2. Valió como desahogo o válvula de escape para las clases populares, a las que se les concedió este placebo con el que saciar sus furores a modo de acto de desagravio o escarmiento simbólico por los perjuicios que la reina mala, indigna, cruel, inmoral...- le había ocasionado a su pueblo: fue una práctica en muchos casos balsámica en lo emocional (los testimonios reflejan la euforia de quienes participan en el entusiasmo destructivo).

3. Por extensión, no dejó de ser un sustitutivo que permitió reconducir la violencia al buscar el concurso visceral de la gente del común pero alejando esa hostilidad del posible ensañamiento con las personas ligadas a la situación anterior, que sin duda habria resultado más lamentable.

4. Se convirtió en una fiesta que solemnizaba el triunfo de La Gloriosa y funcionó como un reclamo movilizador para seducir a esas clases populares; y al mismo tiempo, como demostración o expresión pública de las simpatías revolucionarias de quienes tomaban parte en ella, que experimentaron paralelamente un proceso de socialización y aprendizaje político, en un contexto en que la geografía simbólica de la ciudadanía mudará (empezando por un nomenclátor callejero que se "desborboniza").

5. Se trataba de una práctica que, aunque tuvo sus detractores, concitó la avenencia de gente que realmente suscribía proyectos inconciliables, facilitando asi un efimero consenso sobre lo que habia que echar abajo, lo que se detestaba, y sobre lo cual quiso aplicarse un intento de damnatio memoriae contemporánea.

6. Era también una profanación desacralizadora: la de una imagen considerada hasta entonces sagrada (reina dei gratia). Desde este punto de vista, la transgresión fue máxima cuando, por ejemplo, se quemaba un retrato, acto en el que también subyacía algo de auto de fe purificador.

7. No dejó de constituir un galón para futuros liderazgos políticos a escala local: quien pronunciase frases del tipo "yo estuve en el grupo que arrastró el busto" podía verse imbuido de una autoridad moral y de un aura legendaria deslumbrante para correligionarios más jóvenes de otra generación.

8. Encerraba también una faceta casi de hito fundacional para un relato mítico que remontase a ese momento el inicio de la nueva era democrática, al menos en el imaginario de quien identificase la revolución con el umbral que le dio comienzo.

9. Como corolario de todo lo anterior, y aceptando que pudo haber excesos en algunos casos, sería muy reduccionista limitarse a ver en la iconoclasia politica del 68 un simple impulso patológico que mueve a la destrucción ante el vacío de poder.

Esa violencia simbólica, que representó también el principal punto de encuentro entre quienes protagonizaron o apoyaron la revolución y estaban de acuerdo en lo que tenía que desaparecer - pero no en lo que debía sustituirlo-, pronto dio lugar a otras iconoclasias y luchas por resignificar el espacio público de acuerdo con proyectos culturales y políticos específicos y divergentes. De hecho, poco tiempo después -ya entre octubre y diciembre de 1868-, los republicanos impulsaron manifestaciones en toda España con una simbología 
propia, mientras que los monárquicos defensores de otro modelo de monarquía hacían lo propio. Así, una parte de las luchas políticas para definir el futuro del país a corto plazo se libraría en el plano simbólico y en los espacios públicos, donde se exhibieron lemas, banderas, pancartas y un sinfin de emblemas, como formas visuales de los discursos que se leían en la prensa o se oían en las tribunas.

Enviado el (Submission date): 12/04/2019

Aceptado el (Acceptance Date): 7/05/2019 